$$
\begin{gathered}
N 60-07-05 \\
(195)
\end{gathered}
$$

\title{
RAIL TIEDOWN TESTS WITH HEAVY CASKS FOR RADIOACTIVE SHIPMENTS
}

S. F. PETRY

\section{TIS FILE \\ RECORD COPY}

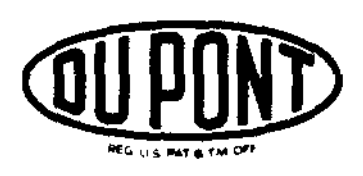

E. I. du Pont de Nemours \& Co. Savannah River Laboratory Aiken, SC 29808 


\section{DISCLAIMER}

This report was prepared as an account of work sponsored by the United States Government. Nelther the United States nor the Unlted States Department of Eneroy, nor eny of their employese, make any warranty, express or implied, or assumes ony legal liability or responsibility for the eccuracy, completeneas, or uestulneas of any information; apparatus, product, or procese disclosed, or represents that its use would not infringe privately owned righte. Reference harein to any epecific commercial pro. duct, process, ar service by trade name, mark, manufacturer, or otherwies does not necesarilly constitute or imply its endorsument, recommendation, or fovoring by the United States Government or any agency thereof. The vlews and opInione of authors expressed herein do not necescarity state or reflect thow of the United Stetes Government or any agency thereof.

Printed in the United States of America

$$
\text { Available from }
$$

National Technical Information Service

U. S. Department of Commerce

5285 Port Royal Road

Springfield, Virginia 22161

Price: Printed Copy A04; Microfiche A01 


\section{DP-1536 \\ Distribution Category: UC-71}

\section{RAIL TIEDOWN TESTS WITH HEAVY CASKS FOR RADIOACTIVE SHIPMENTS}

\section{S. F. PETRY}

Approved by

G. F. Merz, Research Manager

Nuclear Engineering Division

Publication Nate: August 1980

E. I. du Pont do Nemours \& Co.

Savannah River Laboratory

Aiken, SC 29808

PREPARED FOR THE U. S. DEPARTMENT OF ENERGY UNDER CONTRACT DE-AC09.76SR00001 
A rail tiedown test program was conducted at the Savannah River Plant in July and August 1978. For each test, a 40- or 70-ton cask was secured on a railcar. The railcar was pushed to speeds up to $11 \mathrm{mph}$ and allowed to couple to parked railcars simulating ordinary railyard operations. The test car carrying the cask was heavily instrumented to measure the accelerations and forces generated at strategically selected places. Eighteen test runs were made with different combinations of railcars, couplers, casks, speeds, and tiedown configurations. The major objectives of the test program were to 1) provide test data as a basis to develop a tiedown standard for rail cask shipments of radioactive materials and 2) collect dynamic data to support analytical models of the railcar cask tiedown system.

The optimum tiedown configuration demonstrated for heavy casks was a combination of welded, fixed stops to secure the cask longitudinally and flexible cables to restrain vertical and lateral cask movement. Cables alone were inadequate to secure a heavy cask to a standard railcar, and bolting was found disadvantageous in several respects. The use of cushioning coupler mechanisms dramatically reduced the tiedown requirements for the rail coupling operation. This report describes the test program and discusses general conclusions. 
Introduction

Objectives

Planned Analysis

Controlled Test Variations

Preliminary Testing

Test Preparation

Monitoring

General

Accelerometers

Load Cells

Photography

Passive and Other Measurements

Field Fabrication Requirements

Description of Tests

General

Tests 1 and 2

Tests 3,4 , and 5

Tests 6, 7, 8, and 9

Tests 10 and 11

Tests 12 and 13

Tests 14 and 15 
CONTENTS Contd.

Page

No.

Test 16

35

Tests 17 and 18

35

Results

38

Measured Responses

Observations

51

Appendix - Planned Test Preparations 53

Seaboard Coastline Railcars 53

Separate Prefabrication 53

Hallam Cask Cradle 54

Union Carbide Railcar 54

References 
Page

No

1 Rail Tiedown Test Program

31

2 Measured Test Forces

38

3 Effect of Coupling Mechanism

44

4 Effect of Slack Cables

47 
1 Flat, Bulkhead - C1ass P-22

2. Flat, Bulkhead - Class PS-22

3 Converted Union Carbide Railcar Loaded with 40-Ton Hallam Cask

4 Hallam Cask in Modified Cradle on SCL P-22 Railcar Test No. 1

5 70-Ton SRP Cask on SCL P-22 Railcar -

Test Nos. 10 and 11

6 Hallam Cask Tied to Union Carbide Railcar with Cables 18

7 Arrangement of Casks on SCL P-22 Railcar 19

8 Sandia Data Acquisition System 21

9 Accelerometers Mounted on Test Railcar 23

10 Six-Inch-Diameter Load Cell 24

11 Instrumented Coupler and Displacement Gage 25

12 Instrumented Tiedown Load Rolt 26

13 Instrumented Clevis $P$ in 28

14 Reference Grid Board Behind F,OC, Coupling Device 29

15 Hallam Cask Arrangement for PS-22 Railcar 32

16 Modifications and Installation of Hallam Cask Cradle
on Inion Carbide Railcar

17 Bent Stanchion on Hallam Cask Cradle
After Test No. 15

18 Coupler Force vs. Natural Frequency 40 
19 Longitudinal Force vs. Natural Frequency

20 Coupler Force - 40-Ton Cask vs. 70-Ton Cask

21 Longitudinal Force - 40-Ton Cask v8. 70-Ton Cask

22. Coupler Force - Std Coupler vs. FOC Device vs. Cushion UF

23 Longitudinal Force - std Coupler vs. EOC Device vs. Cushion Underframe

24 Cable Force - EOC vs. Std Coupler

25 Cable Force - Taut vs. Slack Cables (EOC)

26 Cable Force - Taut vs. Slack Cables (Std)

27 Ten-Cable Tiedown of Hallam Cask Cradle to Union Carbide Railcar 
RAIL TIEDOWN TESTS WITH HEAVY CASKS FOR RADIOACTIVE SHIPMENTS

\section{INTRODUCTION}

Original plans to conduct railcar coupling tests at the Savannah River Plant (SRP) were intended to support development of a Reactor Development and Technology (RDT) standard for tiedown of radioactive casks to railcars. This activity is part of a technical support program at the Savannah River Laboratory (SRL) for the Department of Energy (DOF), Division of Reactor Research and Technology (RRT). Development of the RDT standard has been closely associated with the work of the American Nationa 1 Standards Institute (ANSI) Subcomittee $\mathrm{N}-582$, with the expectation that the RDT standard will, in substance, also become an ANSI standard.

A draft of RDT Standard F 8-12, Fuel Shipping Container Tiedown for Rail Transport (based upon an approximate analytical approach developed by experienced members of the ANSI subcomittee), was prepared in March 1977 . The tiedown requirements calculated from this draft appeared to be too conservative and economically impractical after further review. The conservative requirements were imposed because there was no test information related to the dynamic behavior of the car and the heavy cask system. A key conservative assumption was that the cask/car system was rigid. The system actually had inherent flexure under shock loadings that tended to absorb and cushion the forces. Complex analyses of these effects have been attempted as indicated in References $2,3,4$, and 5 , but the analyses depended heavily upon assumed values of material and structural properties.

To provide data necessary to develop a more realistic and practical standard for tiedown of rail casks, SRL began planning for field testing cable and bolt tiedowns of shipping casks to railcars. Data recorded during these tests permit evaluation of calculations based upon analytical models. The models can then be confirmed or adjusted to conform with known results.

The SRL test plans were expanded in 1977 to accommodate a request of the Nuclear Regulatory Cormission (NRC) to support closely related programs at Sandia Laboratories and Hanford Engineering and Development Laboratory (HEDL). A similar DOE 
program at Los Alamos Scientific Laboratory (LASL) was also considered. SRL retained prime responsibility for testing. Sandia accepted responsibility to gather and record data for all the laboratories. HEDL and LASL participated in advisory capacities.

\section{OBJECTIVES}

The objectives of the four laboratories associated with the test program are given below.

SRL: Provide test data as a basis for development of a rail cask tiedown standard for radioactive shipments

SANDIA: Provide a generic definition of the environment of the cask/car interface for use in developing licensing guidelines

HEDL: Obtain data to calibrate and verify an analytical model of the railcar cask tiedown system

LASL: Correlate actual test experience with the Railcar Impact Cargo Tiedown Loads (RICTL) computer program

\section{PLANRED ANALYSIS}

Both NRC and DOE supported the testing program to assist in developing analytical techniques to predict tiedown forces for conditions within and beyond the range of the benchmark tests. Los Alamos Scientific Laboratory will correlate actual test data with the RICTL computer program, a lumped parameter approach to mathematical modeling. 5 The major utilization now planned for RICTL is the evaluation of tiedown configurations for variations in impact speed to determine the effect on the cask itself. Ultimately, RICTL results will be extrapolated to possible accident conditions .

Similarly, Hanford Engineering Development Laboratory is developing a mathematical model of the railcar/cask tiedown system that will be verified and adjusted as necessary with the data from these tests. Parametric and sensitivity studies will be conducted with this model to determine coefficients that characterize the influence of each parameter. The model will then be used to establish criteria for tiedown structure of casks to railcars in certification studies for licensing radioactive packages. 
Sandia Laboratories will use the test data to develop a generic definition of the environment of the cask/car interface. This definition will subsequently be used to develop licensing guidelines.

SRP, in association with the ANSI N582 subcommittee for rail tiedown and the Open Top Loading Rules Comittee of the Association of American Railroads, will coordinate the development of an RIT Standard (F 8-12), Fuel Shipping Container Tiedown for Rail Transport. 1 This work is part of the shipping program of the Reactor Research and Technology Division of DOE being conducted by SRJ.

\section{CONTROLLED TEST VARIATIONS}

The independent variables in the test program were

- Railcar type

- Railcar coupling mechanism

- Cask weight

- Coupling speed

- Tiedown configuration

- Natural frequency of the cask tiedown system

SRP selected two Seaboard Coastline (SCL) flat, bulkhead cars (Figures 1 and 2) for the original test plans. Each of these cars had a comparable lightweight (i.e., empty weight) of about 75,000 pounds and had a capacity of 70 tons. A third railcar was later added to the test program because it could be specifically modified for these tests. The third car had been an overseas U. S. Army car for transporting armored tanks. Union Carbide Corporation converted it to a railcar for transporting canisters placed in a welded, "saw-toothed" rack superstructure added to the top of the car (Figure 3). When the three-wheeled truck railcar was converted, Union Carbide also upgraded the car to a nominal capacity of 80 tons. 


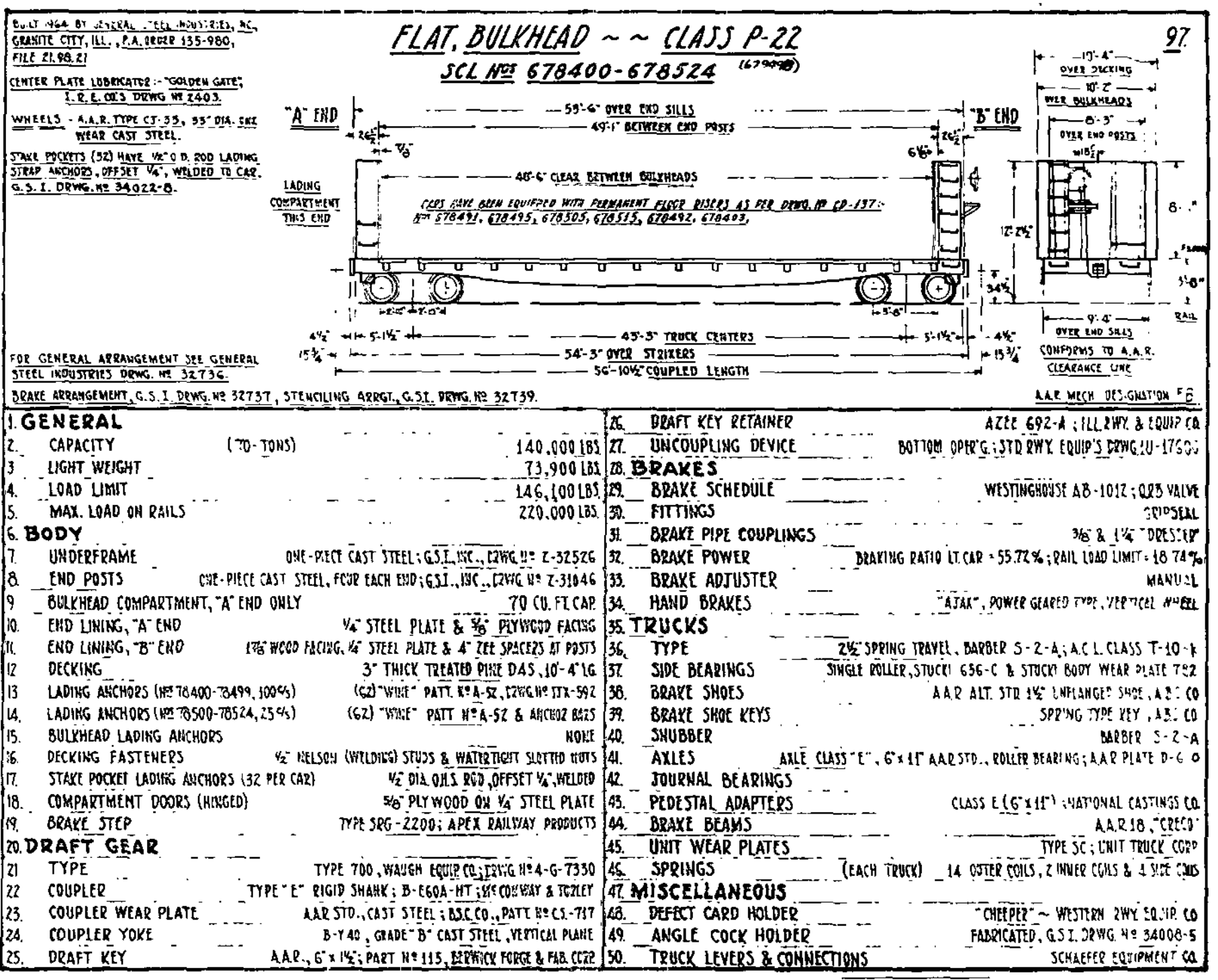

FIGURE I. Flat, Bulkhead - Class P-22 


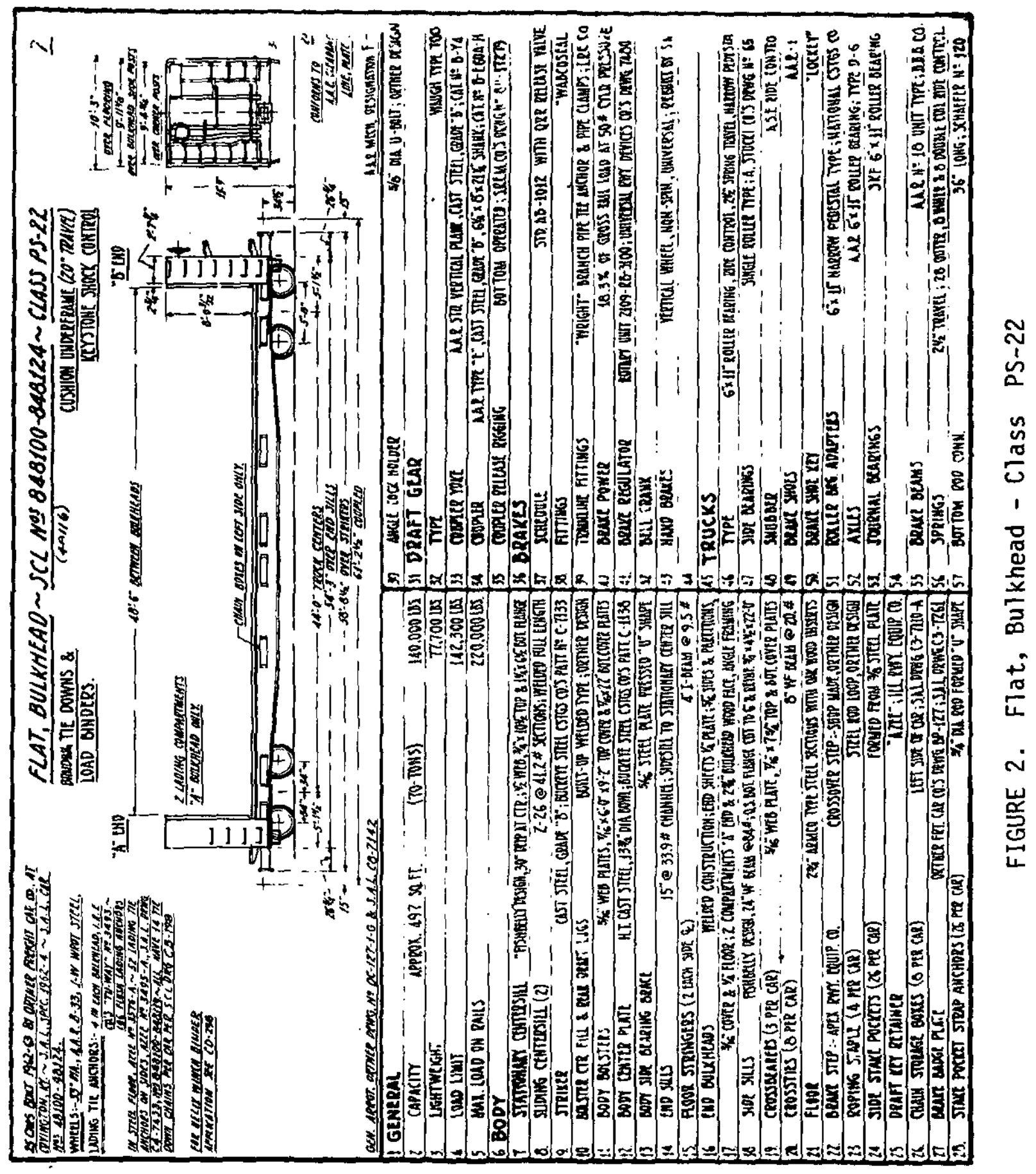




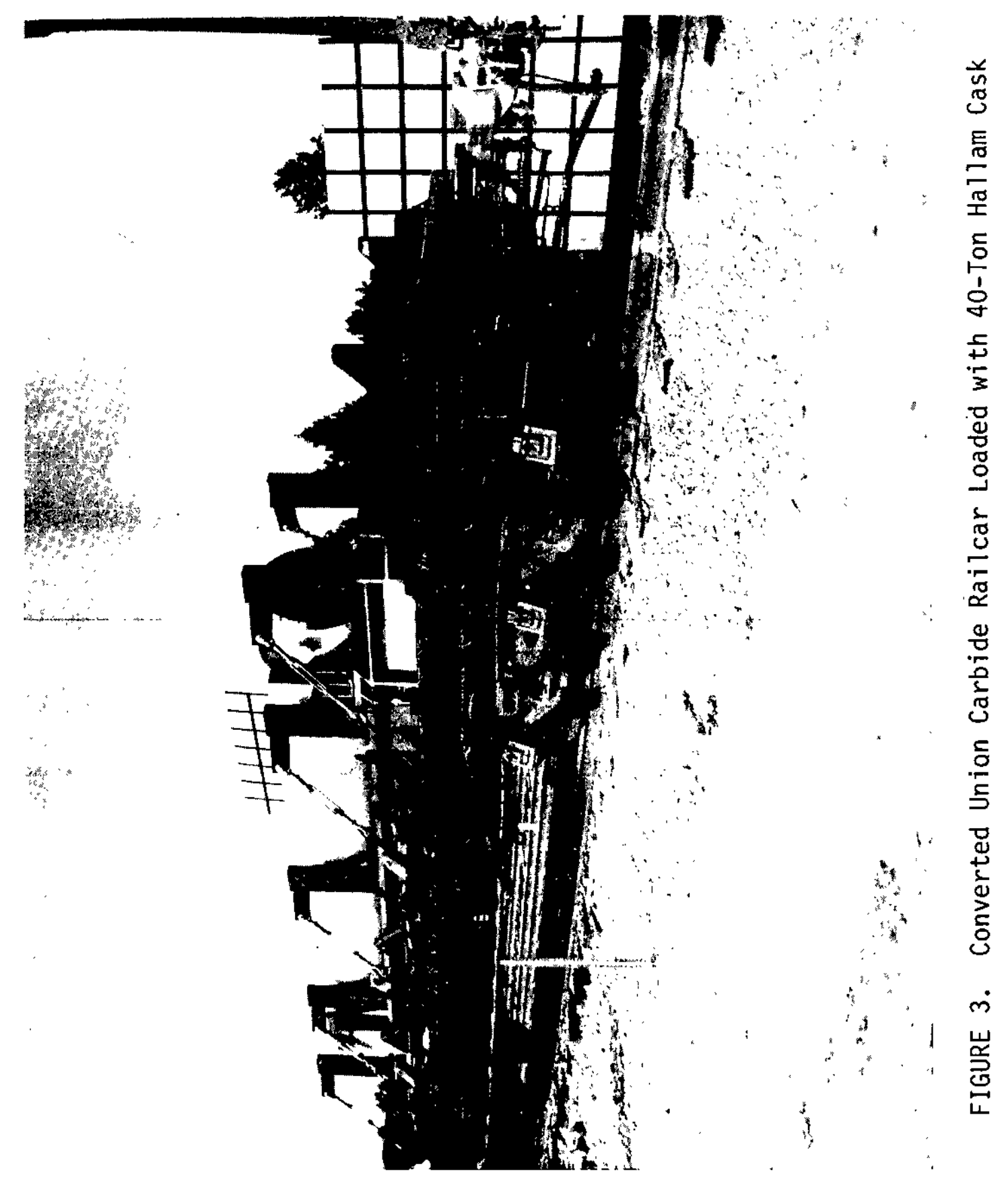


The principal difference between the two SCL railcars was in the coupling mechanism. One car (Figure 1) was equipped with a standard six-inch draft key allowing about 2-1/2-inch coupler trave1, and the second car (Figure 2) had a cushion underframe allowing about 20 inches of coupler travel. The special Union Carbide car was equipped with a standard coupling mechanism on one end, and a 15-inch travel end-of-car (FOC) cushion device was substituted on the other end. This EOC device was manufactured by FreightMaster ${ }^{\oplus}$, a division of the Halliburton Company. The special car thus provided direct comparison of the two coupler mechanisms on the same car.

Most of the available test information relating to rail tiedown involved relatively lightweight loads of 15 tons or less. Since it was anticipated that rail transportation of radioactive casks weighing 100 tons and more would become more frequent in the future, the two heaviest available casks were selected for the test program. One of the casks was the cylindrical Hallam Cask which was normally secured for transportation in a metal-framed "cradle" (Figure 4). Together, the Hallam Cask and cradle weighed about 40 tons. The second cask used in the tests was a rectangular box-shaped 70-t on cask used for onsite shipments at SRP (Figure 5). This cask rested on ten "feet" which were normally bolted to a special trailer during transportation.

An earlier study by Sandia Laboratories ${ }^{6}$ showed that $99.8 \%$ of all train coupling operations occurred at speeds of $11.05 \mathrm{mph}$ or less. For this reason, $11 \mathrm{mph}$ was the most important test speed in the program, because this speed represented a severe tiedown requirement during normal railyard operation. Lower speeds were used in the program as a conservative approach to the $11 \mathrm{mph}$ maximum as well as to test the use of cables as a sole means of cask tiedown.

Except for the special tests with cables used as the only tiedown mechanism, all tiedown configurations included a rigid, welded stop to restrain the cask from moving longitudinally. In combination with this rigid stop, either tiedown bolts or cables were used to secure the Hallam Cask vertically and laterally (Figures 4 and 6 ), whereas bolts only were used to anchor the 70-ton cask feet (Figure 5).

To determine the effect of varying the system natural frequency, a series of three parallel bumper beams was introduced between the base of the cask and the rigid longitudinal stop (Figure 7). The heavy beams were reinforced 14-inch, 8-foot long, 167-pound wide flange (WF) beams. To lower the natural frequency of the system, the middle eight-foot beam was replaced with a one-foot beam, effectively reducing the spring rate between the cask and the stop. 


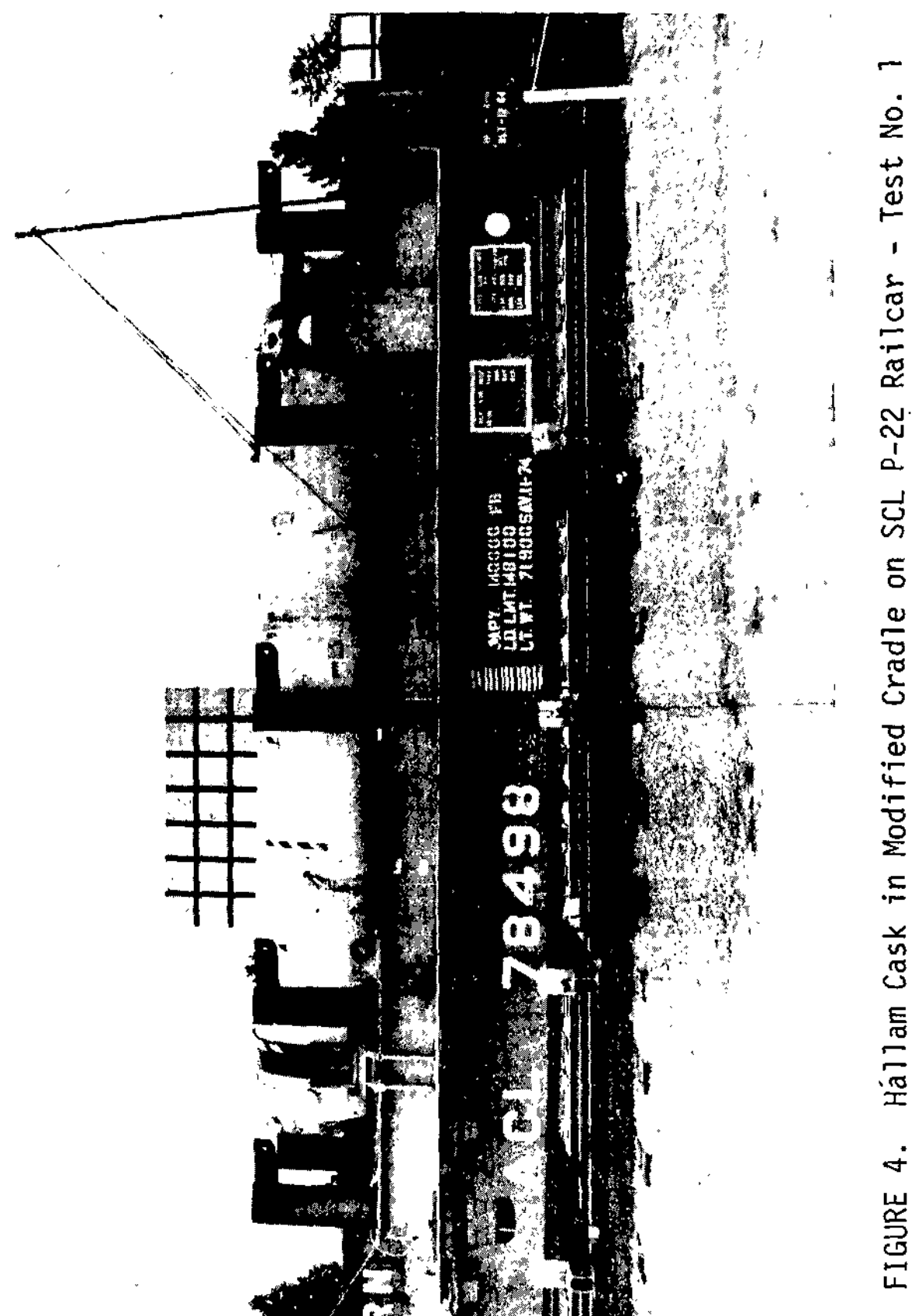




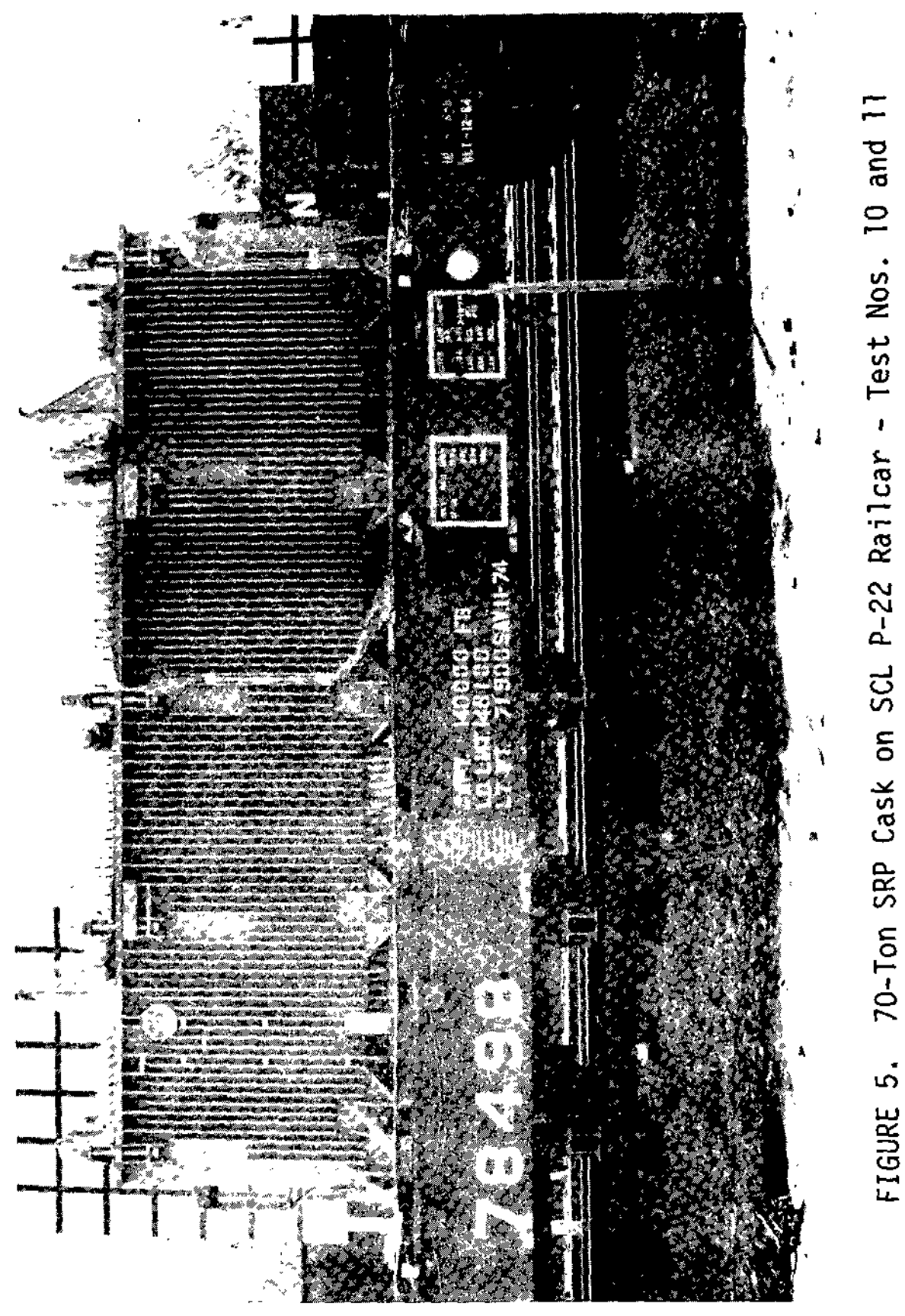




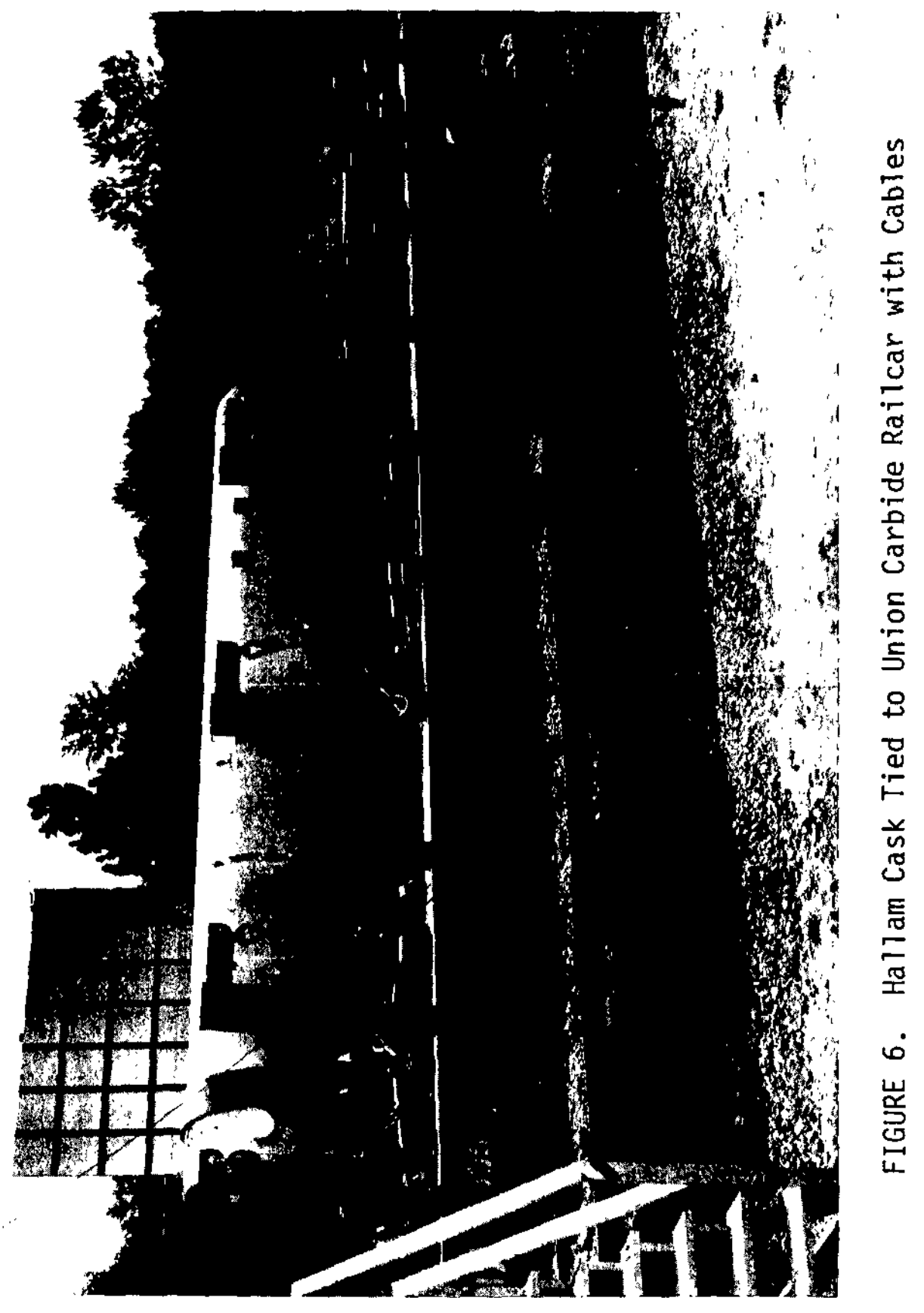




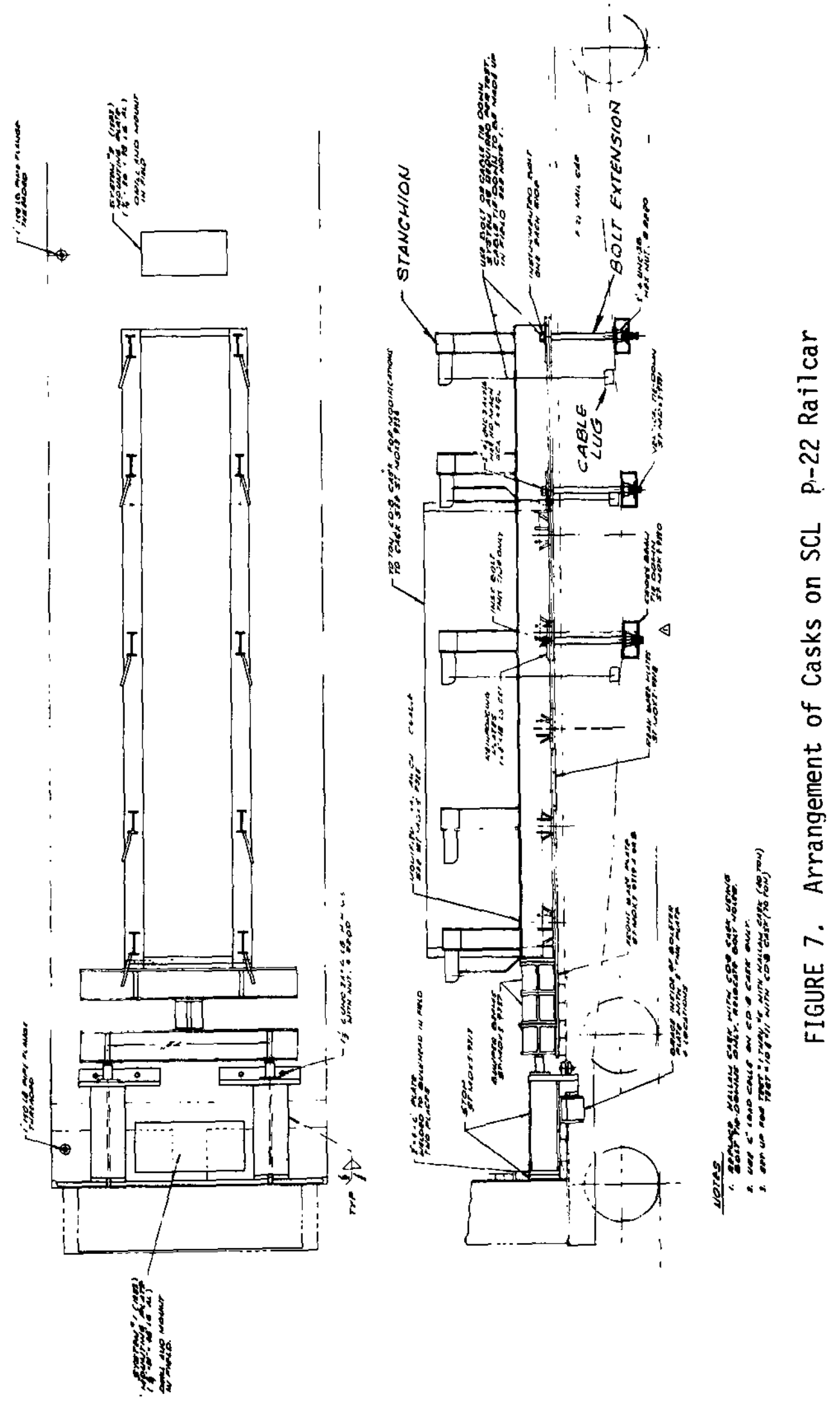




\section{PRELIMINARY TESTING}

A preliminary test sequence was conducted in the classification Yard at SRP on June 8, 1978, to prove the test plans and procedures and to evaluate the structural integrity of an 80-ton Union Carbide railcar. These tests were not instrumented. Concrete weights of 42.5 tons were used to simulate the 40-ton Hallam Cask. Cable rigging secured the weights to the railcar laterally and vertically, and a strong steel stop was welded in place to contain the weights longitudinally. The maximum test speed was $11.8 \mathrm{mph}$.

As a result of the preliminary tests, it was recognized that the coupler draft gear on the Union Carbide car was worn out; and a new standard draft gear was installed on the Union Carbide car to be used in subsequent tests. Also, several changes in photographic planning were made. Otherwise, the procedures and equipment were found satisfactory in the preliminary tests.

\section{TEST PREPARATION}

Extensive shop and field Eabrication was necessary to prepare for the test program. In addition to welding rigid stops and other modifications to the test railcars, adapters such as bolt extensions and beams were prefabricated to accommodate the various tiedown configurations. These preparations were an important and costly part of the program. A more specific description of the planned test preparation is given in the Appendix.

\section{MONITORING}

\section{Generai}

These rail tiedown tests were monitored by recorded instrument data and film coverage together with physical measurements of dimensions, distances, weights, etc. Since all of the major objectives of the tests directly or indirectly depended upon instrument measurements, the most important data gathered were instrumentation signals recorded on tape by Sandia Laboratories. A special van was equipped to receive radio frequency transmission of instrument data. A schematic diagram of this system is given in Figure 8. An electrical transformer was installed at the SRP Classification Yard to supply 208-volt, three-phase power to the Sandia instrument van. Up to 28 separate instrument readings were recorded for a single test with this equipment. Synchronous timing marks were imposed on the data tapes and the high speed film. Track switches positioned a known distance apart measured the impact speed separately. 


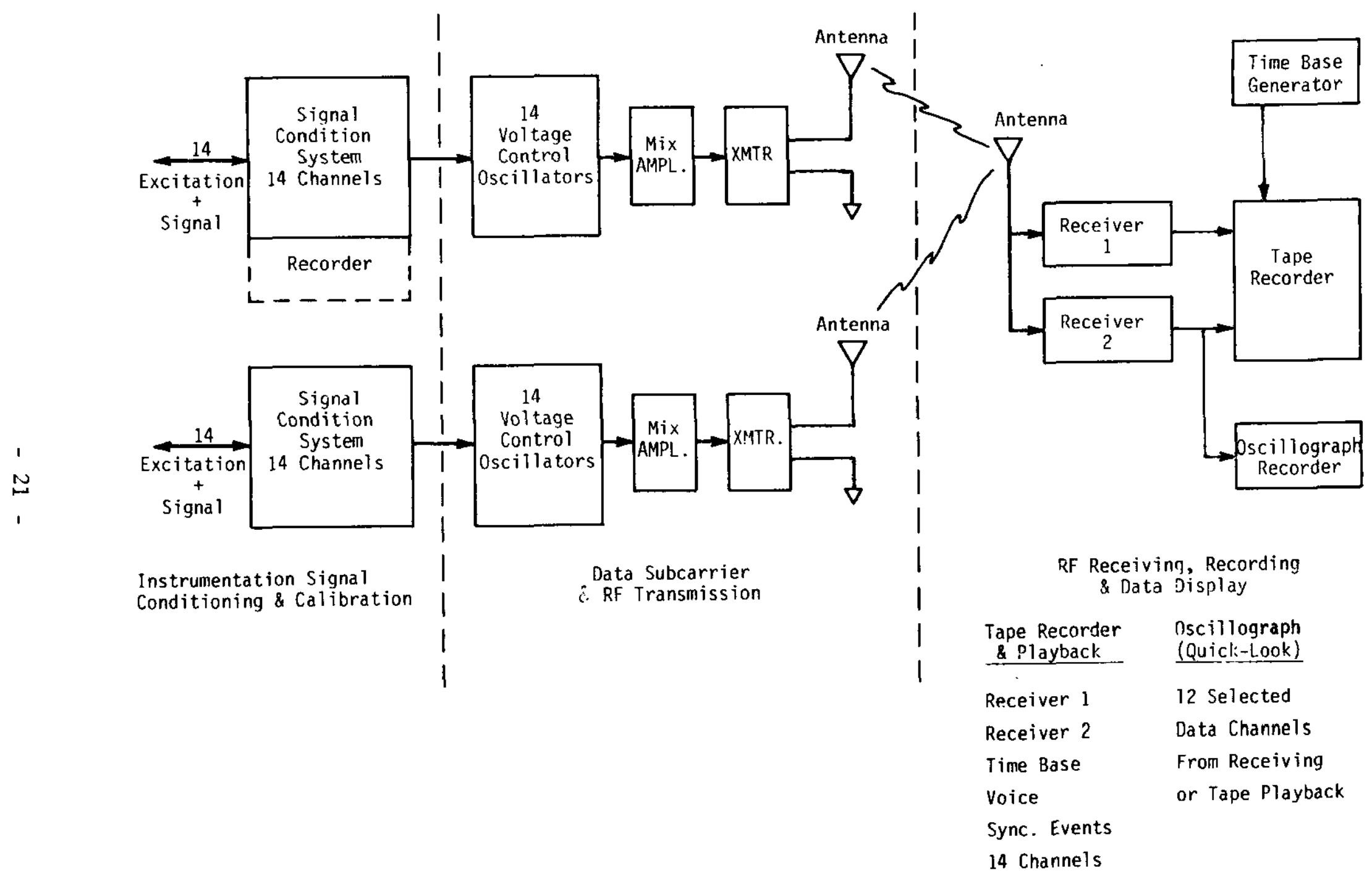

FIGURE 8. Sandia Data Acquisition System 


\section{Accelerometers}

Approximately 20 accelerometer readings were recorded on each test except for those tests in which cables alone were used to tie down the Hallam Cask. Sandia used piezoresistant accelerometers, Endevco, Model 2260-200, for most of their measurements. LASL and HEDL used Endevco piezoelectrical accelerometers, Models 2224-C and 2225. Accelerometers were strategically located by Sandia, LASL, and HEDL on the cask, cask base, railcar structure, and car/ cask interface in positions designed to verify analytical models. Both kinds of accelerometers used are pictured in Figure 9 . They were attached to a railcar structure with dental cement.

\section{Load Cells}

Test forces were measured with four kinds of load cells. The most important load measurements were the longitudinal forces exerted by the casks on the rigid stops. Load cells to determine these forces were designed and calibrated at SRL. Both four-and $s i x$-inch-diameter cells were made, but only the six-inch cells were used after the first two tests for consistency. Figure 10 shows a six-inch load cell attached to a rigid stop at the flanged end. The cell was touching a bumper beam at the other end. In calibrating the four-inch cells, the load readings were not reproducible until after a cell had been loaded at least once. For this reason, the six-inch cells were "exercised" on a press up to 750,000 pounds before they were calibrated. Since the cumulative value measured by two cells was the total longitudinal force exerted on the stops, measurements up to $1,500,000$ pounds should be accurate.

An instrumented coupler leased from National Castings Division of Midland Ross Corporation was used to monitor the actual coupling forces that occurred during impact. Figure 11 shows the instrumented coupler (No. 3) installed together with a displacement gage (No. 4). This coupler was designed to measure forces in the range of $1,250,000$ pounds.

Two-inch-diameter by seven-inch-long load bolts vere fabricated by Strainsert Company to determine the upward force exerted by the cask lifting from the railcar after impact. These bolts (Figure 12) were calibrated up to 100,000 pounds of tensile force. Care was exercised so that the holes in the 70-ton cask feet or the 40-ton cask cradle were considerably larger than the instrumented bolts to avoid shear forces on the bolts. 


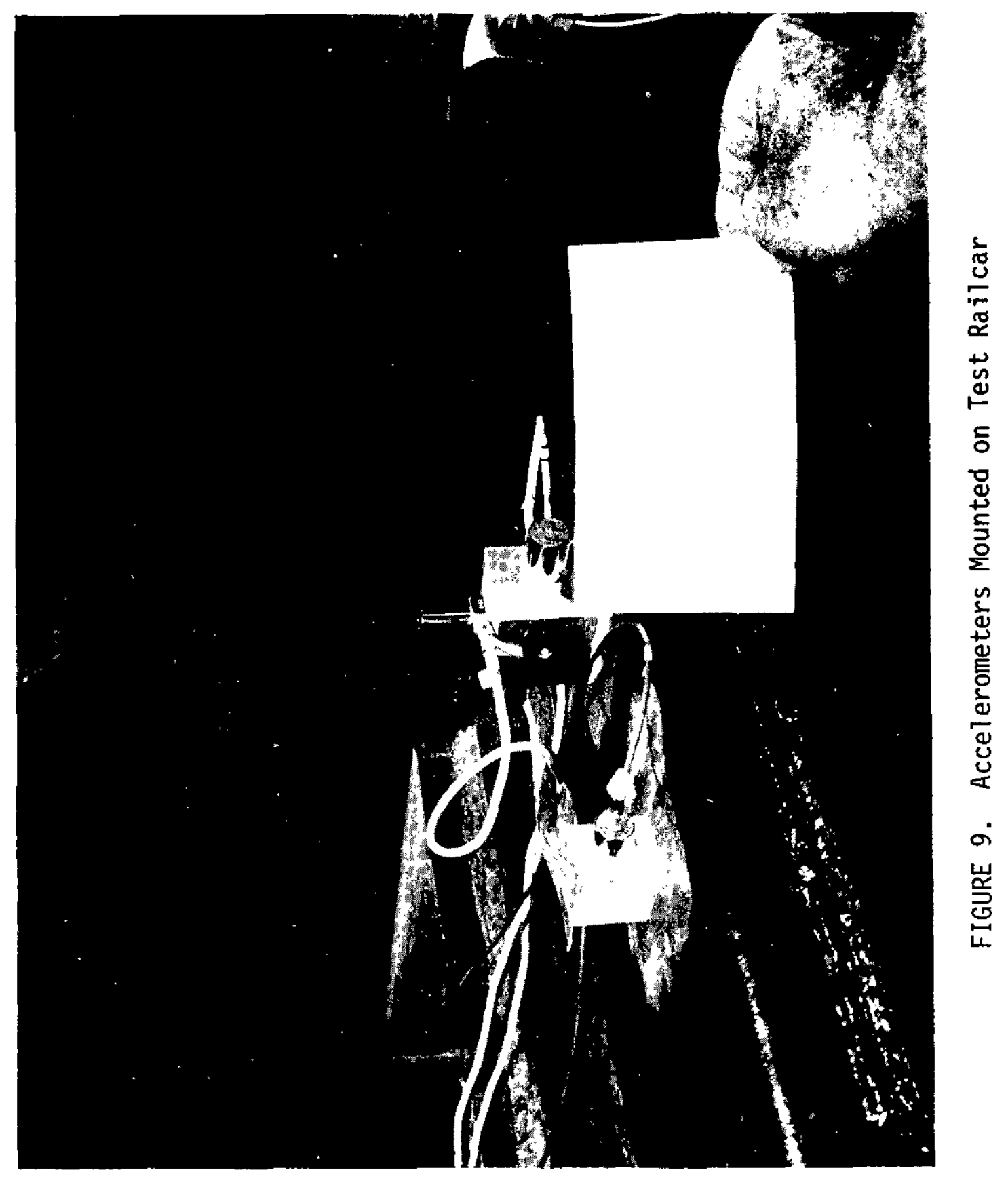




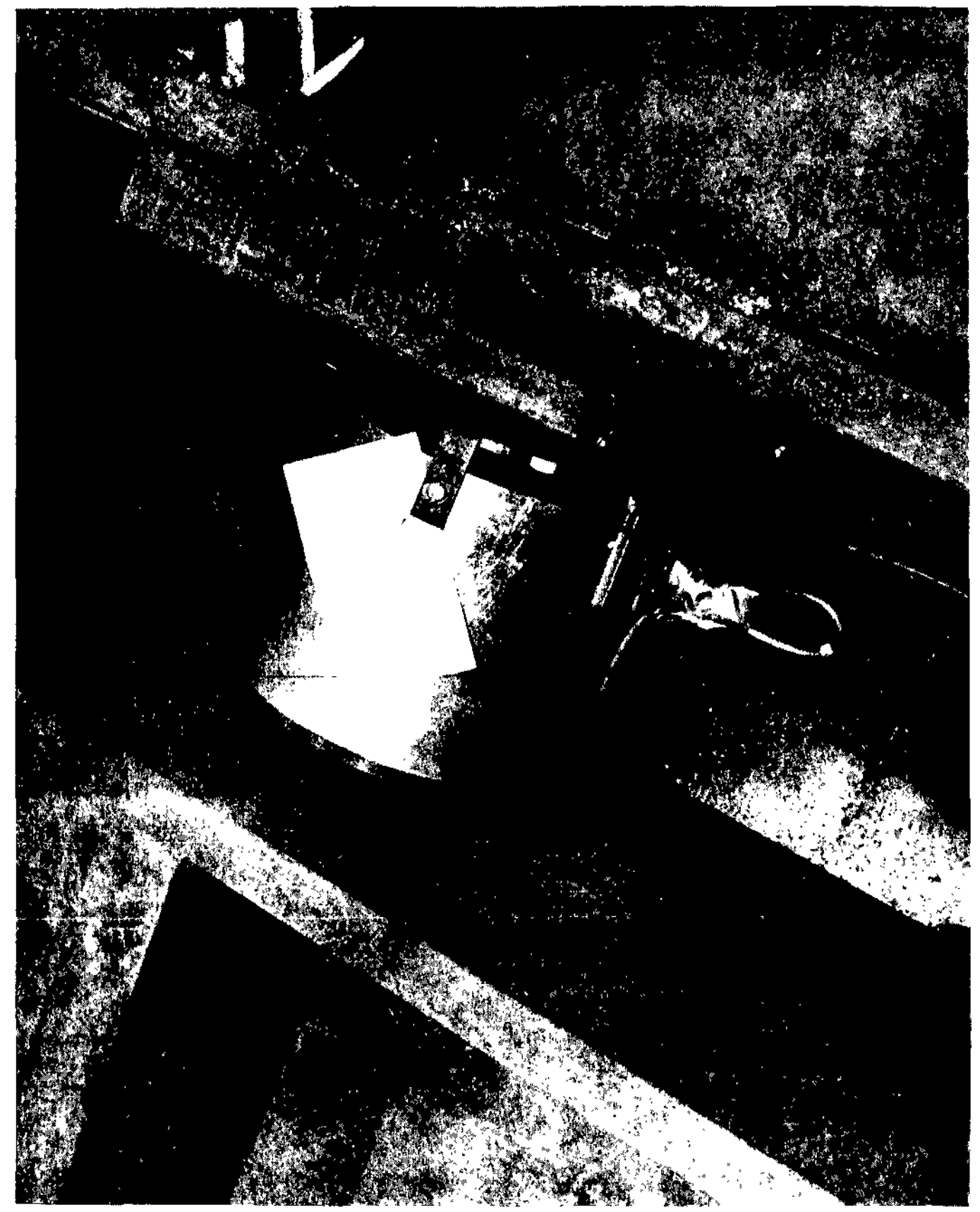

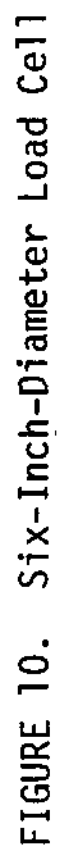




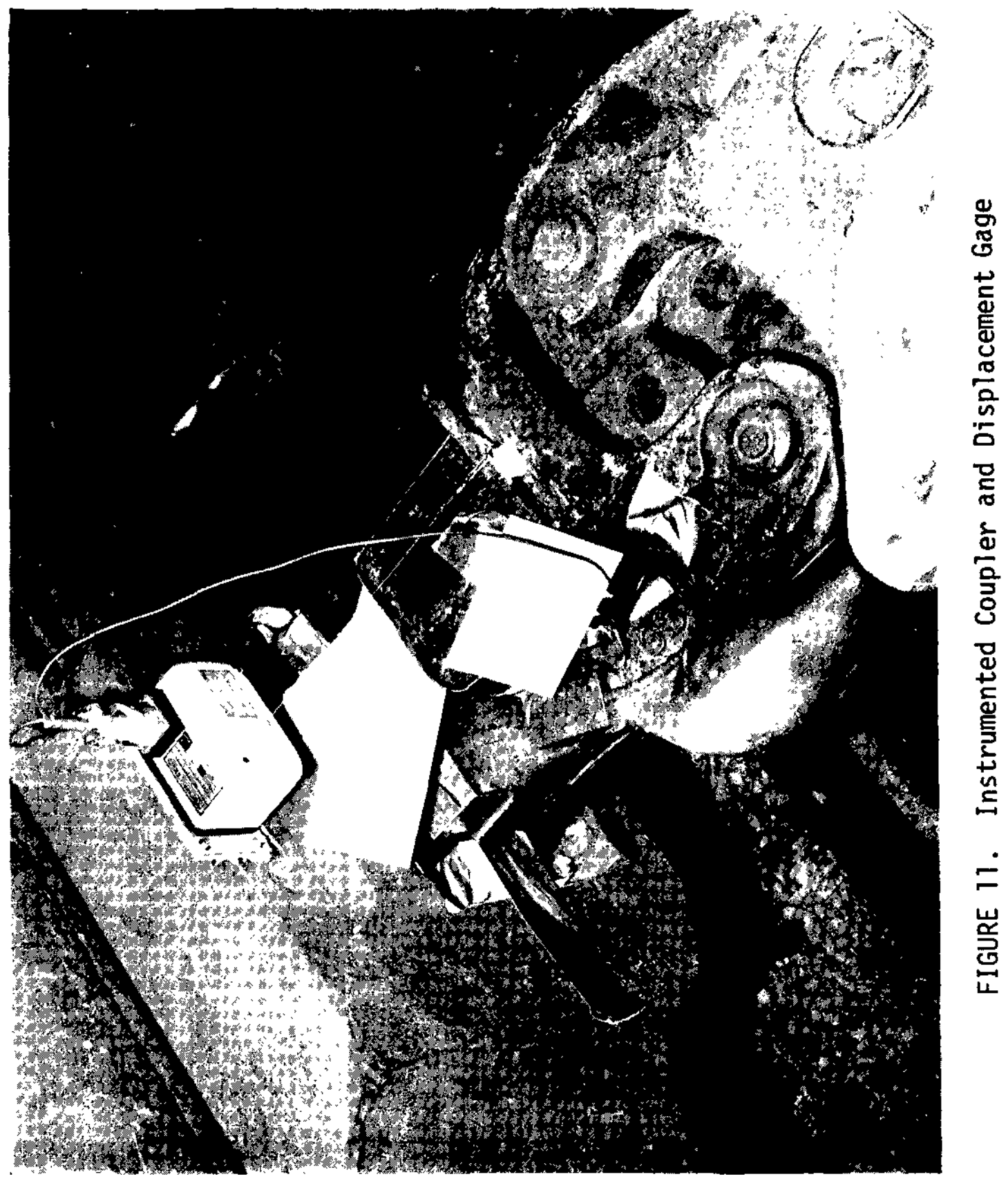




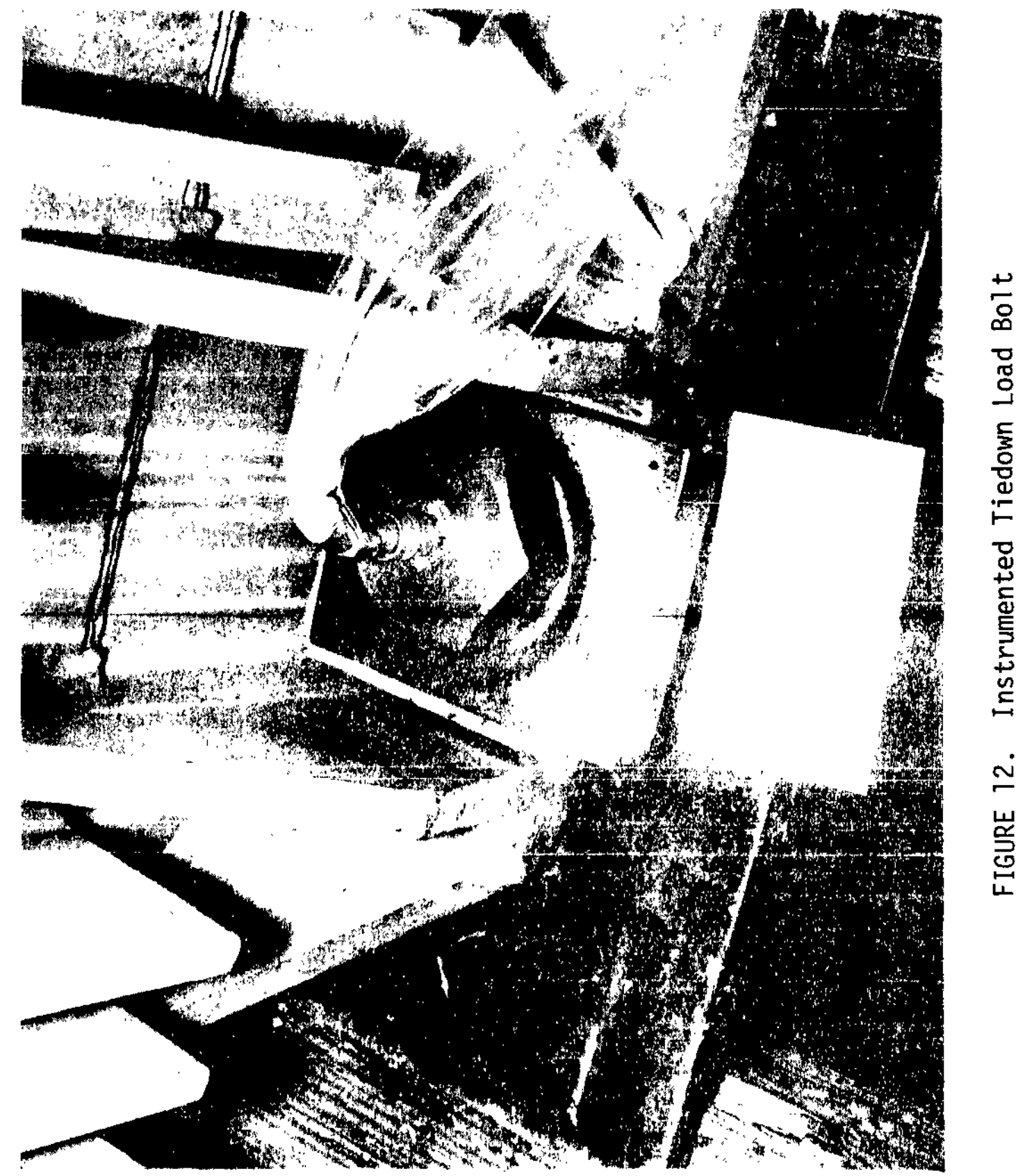


The Strainsert Company also instrumented specially fabricated clevises (Figure 13) to measure cable loads during the tests. The clevis pins were calibrated to 50,000 pounds to measure forces between the safe working load (about 18,000 pounds) of one-inch cables and the break strength (ahout 80,000 pounds).

\section{Photography}

Sandia furnished two high-speed Milliken cameras for the tests. When operable, both cameras were used at 400 frames per second. One, having a reference grid board (12-inch white squares) behind the train as shown in Figure 14, was focused on the couplers. The other camera was most often focused on the top rear of the cask (with a second grid board in the background as shown in Figures 4 and 6) to monitor the vertical motion of the cask after impact. As stated before, both cameras had timing marks imposed on the film synchronized with marks on the data tapes.

\section{Passive and Other Measurements}

A number of passive measurements were made during the test program. The distance from the coupler horn to the striker plate was measured before and after most teats for each of the four "anvil" ballast railcars. The distance each anvil car moved after impact was recorded, and the cask movement was also determined. Simple displacement gages were devised to measure the maximum compression (and extension) of the "hamer" car truck springs. Railcar dimensions were recorded along with the cask position on the car for most tests. The cumulative weight of the four anvil ballast cars was measured at 695,440 pounds. The loaded test cars were weighed at each end to provide a measured means of determining the longitudinal location of the center of gravity.

\section{Field Fabrication Requirements}

In addition to planned shop and field fabrication work for the test program, several unexpected requirements arose that resulted in direct or indirect test delays. A major problem was encountered when the framework dimensions of the SCL P-22 railcar used in the tests were found to be different from those measured earlier on two other SCL P-22 cars in the same number series. The center sill flanges were four inches wider than expected, and those four inches interfered with the planned location of the holddown bolts and extensions. Fxtensive torch cutting of these flanges and other interference areas was therefore necessary. 


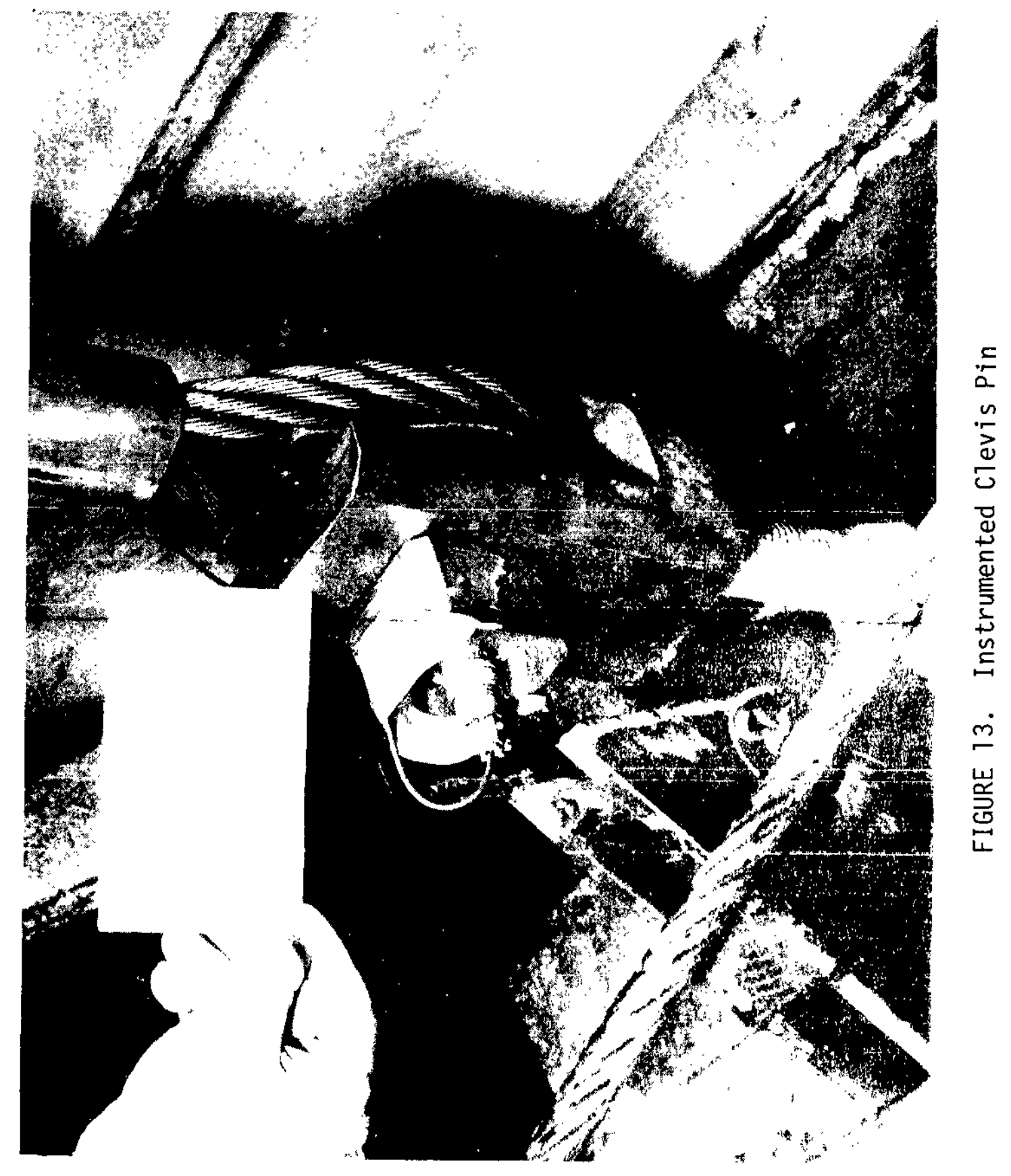




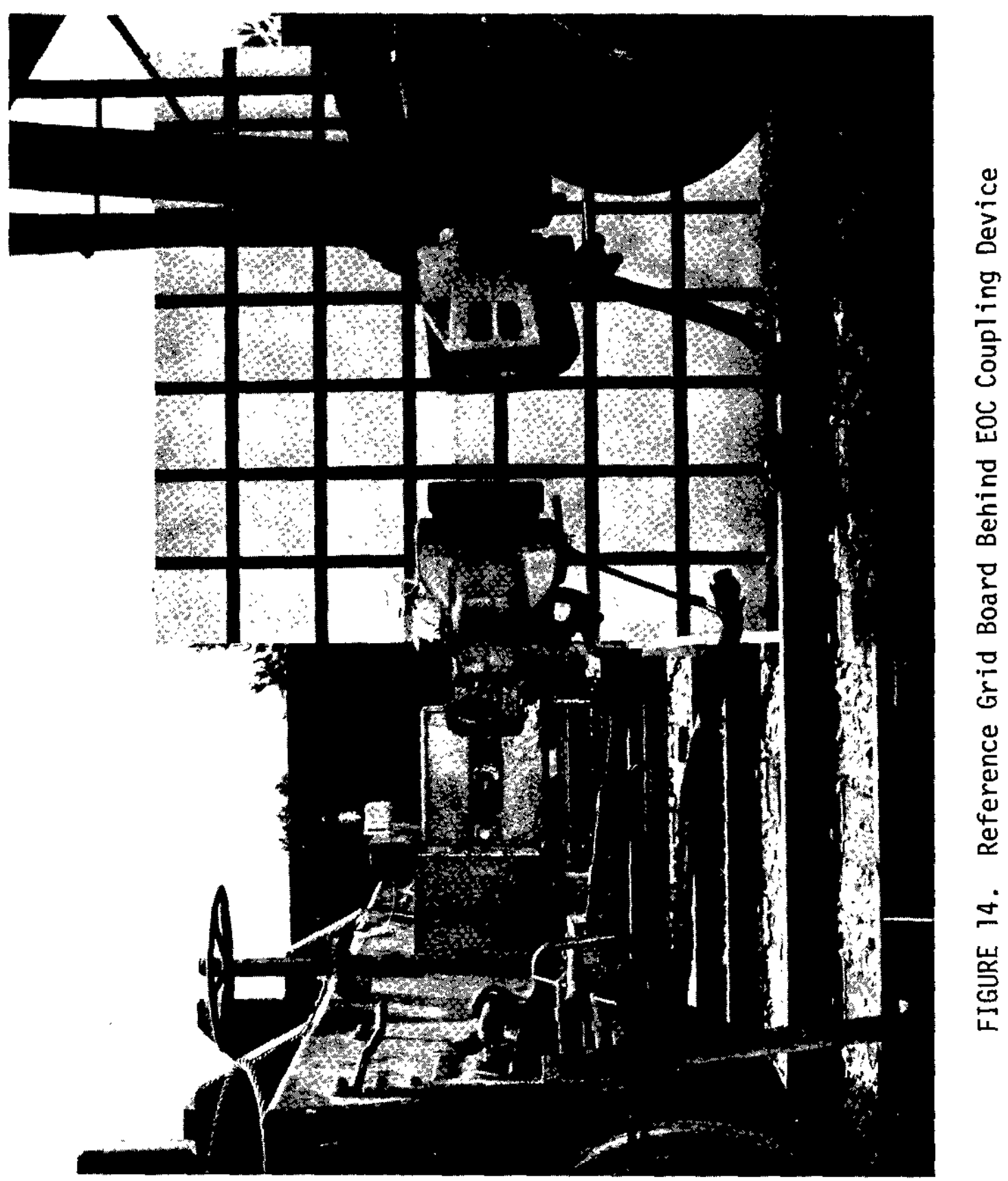


The Hallam Cask used in the tests had trunnions larger than the saddle in the spare cradle, which had been modified for the test program. The trunnion saddle was enlarged in the spare cradle accordingly.

The tiedown cross beams were judged too flexible as prefabricated (Figure 4), so heavy metal plates were welded boxlike around the original beams to atiffen them (Figures 5 and 7 ). The heavy casks depressed the old railcar truck springs more than anticipated so that the bottom nuts used to secure the tiedown bolt extensions were recessed into the stiffened cross beams (Figure 7).

To avoid interference between the cask tiedown bolt extensions and the SCL PS-22 cushioned underframe railcar, the cask was placed about eight inches offcenter in the original design. This eccentricity caused the railcar to tilt dangerously, causing the tiedown bolt extensions to almost touch the track on one side. The eccentric loading tests were therefore cancelled, and Tests 17 and 18 (Table 1) were substituted with the cask and railcar aligned and the cask secured with cables instead of bolt tiedowns (Figure 15).

\section{DESCRIPTION OF TESTS}

\section{General.}

The coupling tests were conducted in the Classification Yard of SRP near Barnwell, South Carolina. A loaded test car was pushed by a locomotive up to a predetermined speed and released (free-wheeling) to couple to four heavy $(695,440$ pounds tota1) ballast cars. Using a radar unit to determine approximate speed $(+1 \mathrm{mph})$, the train crew developed a technique which usually resulted in impact speeds within $0.5 \mathrm{mph}$ of those intended. The track was graded so that the test car maintained about the same speed at impact as that when released approximately 100 yards up the track. To maximize the impact force, the mechanical brakes were set on all four ballast cars. (Note that the air brakes were intentionally disconnected to avoid variation due to air bleeding off.) Before each test, the locomotive pulled the anvil ballast cars a few feet beyond the impact point and then pushed the cars back into position to remove the slack in the car couplers at initial impact.

All of the tests are summarized in Table 1 to provide an overall comparison of test variations. Each of the tests is discussed in the following subsections. 
TABLE 1

Reil Tiedown Test Program

\begin{tabular}{|c|c|c|c|c|c|c|c|c|}
\hline $\begin{array}{l}\text { Test } \\
\text { No. }\end{array}$ & Date & $\begin{array}{l}\text { Rais }{ }^{+} \\
\text {Car }\end{array}$ & Coupler & $\begin{array}{l}\text { Cask Wh. } \\
\text { ton }\end{array}$ & $\begin{array}{l}\text { Impact } \\
\text { Speed, mon }\end{array}$ & $E_{n}{ }^{*}$ & Tredown $^{{ }^{4}}$ & Remarks \\
\hline 1 & $7 / 14$ & I & Standard & 40 & 8.3 & $\mathrm{H} 2$ & A & Instrumented Coupler Foulty \\
\hline 2 & $7 / 18$ & I & Standard & 40 & 9.1 & $\mathrm{H}_{1}$ & A & Inotrumented Coupler Faulty \\
\hline 3 & $7 / 19$ & I & Standard & 40 & 10.5 & $\mathrm{Hi}$ & A & \\
\hline 4 & $7 / 19$ & I & Scandayd & 40 & 10.7 & Low & B & \\
\hline 5 & $7 / 20$ & I & St and ard & 40 & 10.5 & $\mathrm{H}_{1}$ & D & Cabie Load Instruments Faulty \\
\hline 6 & $7 / 26$ & III & EOC* & 40 & 2.8 & - & c & No Photography \\
\hline 7 & $7 / 26$ & II I & EOC & 40 & 5.6 & - & c & No Photography \\
\hline 8 & $7 / 26$ & III & EOC & 40 & 9.2 & - & c & No Photography \\
\hline 9 & $7 / 26$ & III & EOC & 40 & 9.2 & - & $c$ & No Photography, Cables Slack \\
\hline 10 & $7 / 27$ & I & St andard & 70 & 8.0 & - & A & One Hiph-Speed Camera Only \\
\hline 11 & $7 / 27$ & $\mathbf{I}$ & Standard & 70 & 11,2 & - & A & One High-Speed Camera Only \\
\hline 12 & $7 / 31$ & II I & EOC & 40 & 11.2 & - & D & Data Questionable \\
\hline 13 & $8 / 1$ & III & EOC & 40 & 11.1 & - & D & Repeat of Test 12 \\
\hline 14 & $8 / 1$ & III & St andard & 40 & 5.4 & - & $c$ & \\
\hline 15 & $8 / 1$ & III & Standard & 40 & 6.5 & - & C & Cables Slack \\
\hline 16 & $8 / 2$ & III & Standard & 40 & 10.8 & - & D & Some Cables Loose After Test \\
\hline 17 & $8 / 3$ & II & Cushion & 40 & 5.9 & - & D & \\
\hline 18 & $8 / 3$ & II & Cushzon & 40 & 10.7 & - & D & \\
\hline
\end{tabular}

* Natural frequency.

* End of car.

+ Ralcars: I 70-ton SCL - Standard Couplers

II 70-ton SCL - Cushion Underframe

I I 80-ton Union Carbide - Maxed Couplers

$+\uparrow$ Tiedown: A. Cask againgt rigid stop (2 load cells and beams between) anchored with vertical bolts (2 instrumented of 6 total).

$B$. Same as $A$, except $F_{n}$ lowered with bumper beams.

C. Ten one-inch cables at same angle (2 instrumented) - no stop.

D. Vertical tiedown with 6 cables (2 instrumented) - cask stopped.

at same angle (2 instrumented) - no stod. 


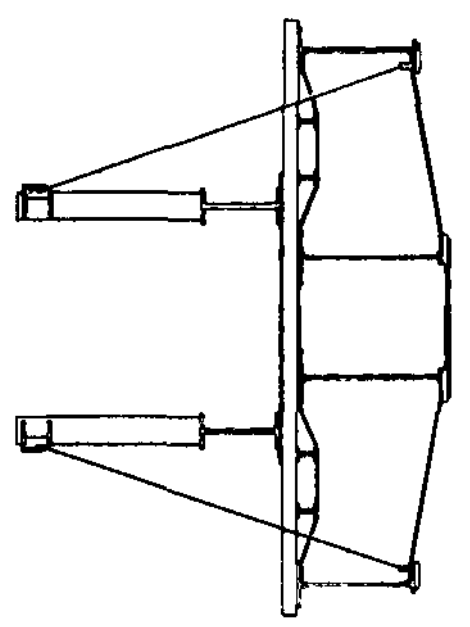

(3)
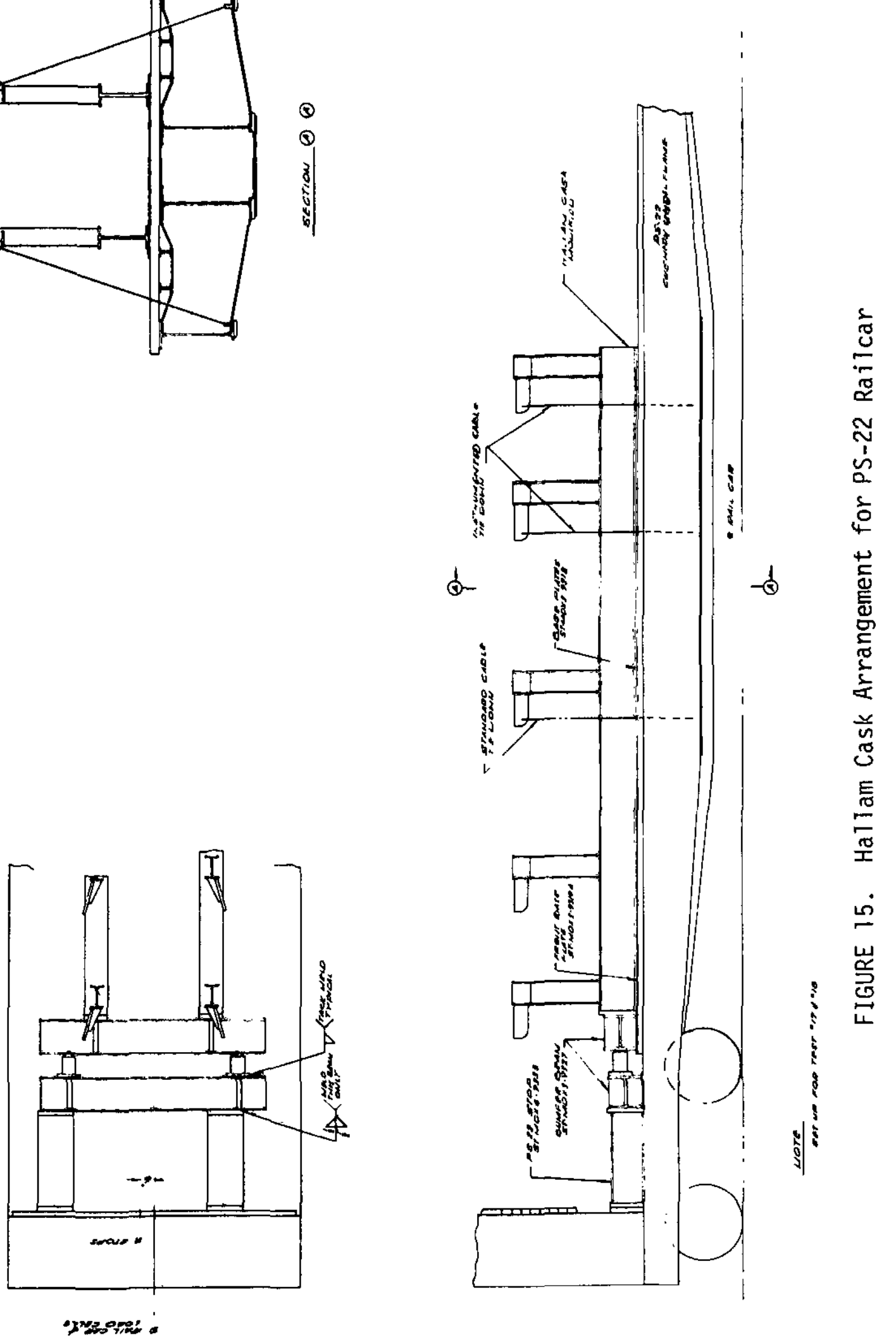
Tests 1 and 2

Test 1 was conducted at 10:00 a.m., July 14, 1978. Actual impact speed was measured at $8.3 \mathrm{mph}$. The standard SCL railcar loaded with the 40-ton Hallam Cask is shown in Figure 4 before the test. Eight tiedown bolts were pretorqued to 125 foot-pounds. All four cross tiedown beams moved forward during impact, so the bolt loads did not remain vertical as intended. One instrumented bolt galled and had to be burned out. The coupler of the lead anvil car bottomed out in a manner indicating that it was badly worn. The instrumented coupler reading was erratic and overranged.

It was decided, after Test 1 , that the cross tiedown beams were too flexible; so each beam was stiffened by welding a "box" of 3/4-inch steel plates around it (Figures 5 and 7 ). The ballast cars were rotated to make the lead anvil car the one with the best coupler draft gear. To make certain the load cells were not under substantial preload, a crane was used to completely unload the cells.

Test 2 was essentially a repeat of Test 1 . Test 2 was conducted at $1: 30 \mathrm{p.m}$., July 18, 1978, at an impact speed of $9.1 \mathrm{mph}$. Only the three rear cross tiedown beams and six corresponding bolts were used. The beams were prevented from moving forward during impact with welded stops. The lead anvil car coupler again bottomed out. The instrumented coupler reading was again erratic, so the coupler was changed out for subsequent tests. A frayed wire, which had rendered the instrumented coupler used in the first two tests defective, was later found.

Tests 3, 4, and 5

Test 3 conditions were the same as Test 2 conditions except for a higher impact speed of $10.5 \mathrm{mph}$. The test was run at $4: 30$ p.m., July 19, 1978. The new instrumented coupler produced a good reading. Test 4 was also run at $7: 00$ p.m., July 19, 1978. The objective was to duplicate Test 3 except that the center eightfoot bumper beam was replaced with a one-foot beam section to lower the natural frequency of the system. The impact speed of Test 4 was $10.7 \mathrm{mph}$. The test caused a bow of approximately $1 / 8$ inch to permanently set in the reinforced bumper beam between the one-fout beam section and the two longitudinal load cells. Test 5 was also intended to duplicate Test 3 except that cables were attached from the cask cradle to lugs on the cross tiedown beams. These six cables replaced the bolts (and extensions) used for vertical tiedown in the previous tests. 
Tests 6, 7,8, and 9

The 40-ton Hallam Cask loaded on the special Union Carbide railcar was used for Tests $6,7,8$, and 9 . The cask cradle was secured to the car only with ten cables at the same angle (Figure 3). The cask was well away from touching the rigid stops. The cask was oriented so that the 15 -inch EOC FreightMaster ${ }^{\circledR}$ coupling device was at the impact end. All cables were pretorqued to about 75 foot-pounds. Test 6 was conducted at 9:40 a.m., July $26,1978$. The impact speed of $2.76 \mathrm{mph}$ was so low that the entire load was taken up in the EOC device, and the cables were not stressed at all beyond the preload. Test 7 was then run at $10: 20$ a.m. at 5.63 mph. Most of the load appeared to be taken up at the coupler spring; however, the cask did slide forward about $1 / 4 \mathrm{inch}$, which indicated additional stress in the cables (measured at about 6000 pounds).

After retorquing the ten tiedown cables to 75 foot-pounds, Test 8 was run at 11:20 a.m., July 26, 1978, at an impact speed of $9.15 \mathrm{mph}$. The cask slid forward about $5 / 8 \mathrm{inch}$. The last test in this series, Test 9 , was designed to duplicate Test 8 except with loose cables. The objective was to learn the effect on tiedown loading when load cables became slack, a common occurrence in rail transportation. Accordingly, the turnbuckles on all cables were intentionally loosened (about two turns) until the cables literally sagged. Test 9 was run at $12: 05 \mathrm{p} . \mathrm{m}$. at the same impact speed as Test 8 . At impact, the cask slid forward about 2 inches, and the cables snapped taut and vibrated.

\section{Tests 10 and 11}

Tests 10 and 11 were run with the 70-ton SRP scrap cask bolted to the standard SCL railcar (Figure 5). Test 10 was conducted at 1l:10 a.m., July 27, 1978, at an impact speed of 8.02 mph. Test 11 was also conducted July 27,1978 , at $3: 00 \mathrm{p} . \mathrm{m}$. It was essentially a repeat of Test 10 at a higher impact speed of $11.17 \mathrm{mph}$. This test was the most severe test in the program. After impact, the anvil cars were driven back 190 inches.

Tests 12 and 13

Test 12 was run with the 40-ton Hallam Cask on the special Union Carbide car impacting at $11.2 \mathrm{mph}$ on the end containing the EOC cushioning unit. The cask (with one bumper beam) was placed against load cells mounted on a rigid, welded stop. Instead of the troublesome bolt tiedown arrangement, cables (almost vertical) 
were used to secure the cask cradle to welded lugs on the railcar (Figures 6 and 16). Test 12 was run at $11: 45$ a.m., July 31,1978 , but the data recording was questionable, and the test was repeated. Accordingly, Test 13 was run at 10:20 a.m., August 1, 1978, at an impact speed of $11.1 \mathrm{mph}$.

Tests 14 and 15

Tests 14 and 15, having the 40-ton Hallam Cask secured to the Union Carbide car with only ten one-inch cables, were similar to Tests 6 through 9 except the impact end of the railcar had a new standard coupler instead of the EOC cushioning device. These tests provided a direct comparison between the standard coupler and the EOC device since the railcar and cask were common to all the tests. Test 14 was conducted at $6: 15 \mathrm{p.m}$. , August 1 , 1978, at a 5.4-mph impact speed. The cask slid forward about $1-1 / 2$ inches at impact. It appeared that the tiedown load at this speed was at least as great as in the 9.2 -mph impact (Test 8 ) with the EOC device. Test 15 was similar to Test 14 except the cables were loosened about two turnbuckle turns to introduce slack. Test 15 was conducted at 7:00 p.m., August 1, 1978, at an impact speed of $6.5 \mathrm{mph}$. The tiedown load at impact was so great that the anchoring stanchions on the Hallam Cask cradle bent noticeably (Figure 17). The cask slipped forward about 3-1/2 inches after impact.

Test 16

Test 16 was designed to provide a reference for Test 13 so that the standard coupler could be directly compared with the EOC device by tests with the 40-ton Hallam Cask against the rigid longitudinal stops of the Union Carbide Test railcar. Tesi 16 was run at 1:55 p.m., August 2, 1978, at an impact speed of $10.8 \mathrm{mph}$.

Tests 17 and 18

The purpose of Tests 17 and 18 was to learn the effect of the cushion underframe coupling mechanism with the 40-ton Hallam Cask tied to the SCL car with near vertical cables. Test 17 was a preliminary low speed $(5.9 \mathrm{mph})$ run on August 3,1978 . Test 18 was also run at about $3: 00$ p.m., August 3,1978 . The impact speed of Test 18 at $10.7 \mathrm{mph}$ was near that of Tests 16 (10.8 mph) and 13 (11.1 mph) to provide comparison of the cushion underframe, EOC, and standard coupling mechanisms. 


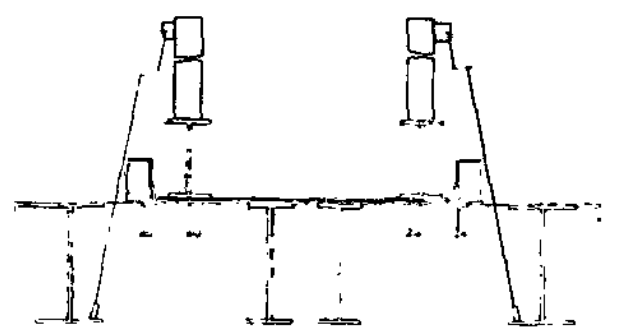

패
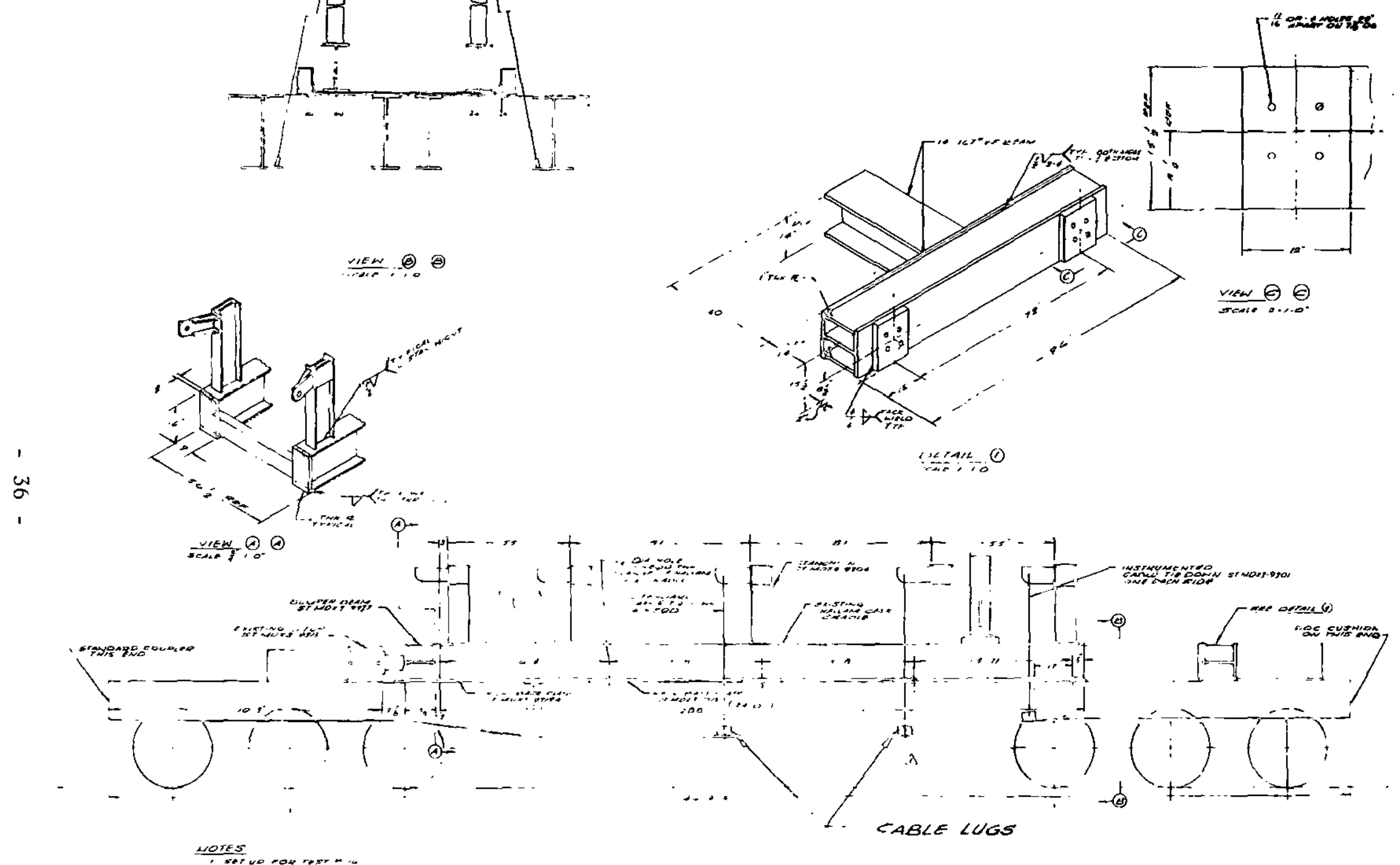

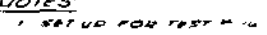

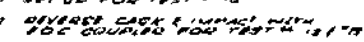

FIGURE 16. Modifications and Installation of Hallam Cask Cradle on Union Carbide Railcar 


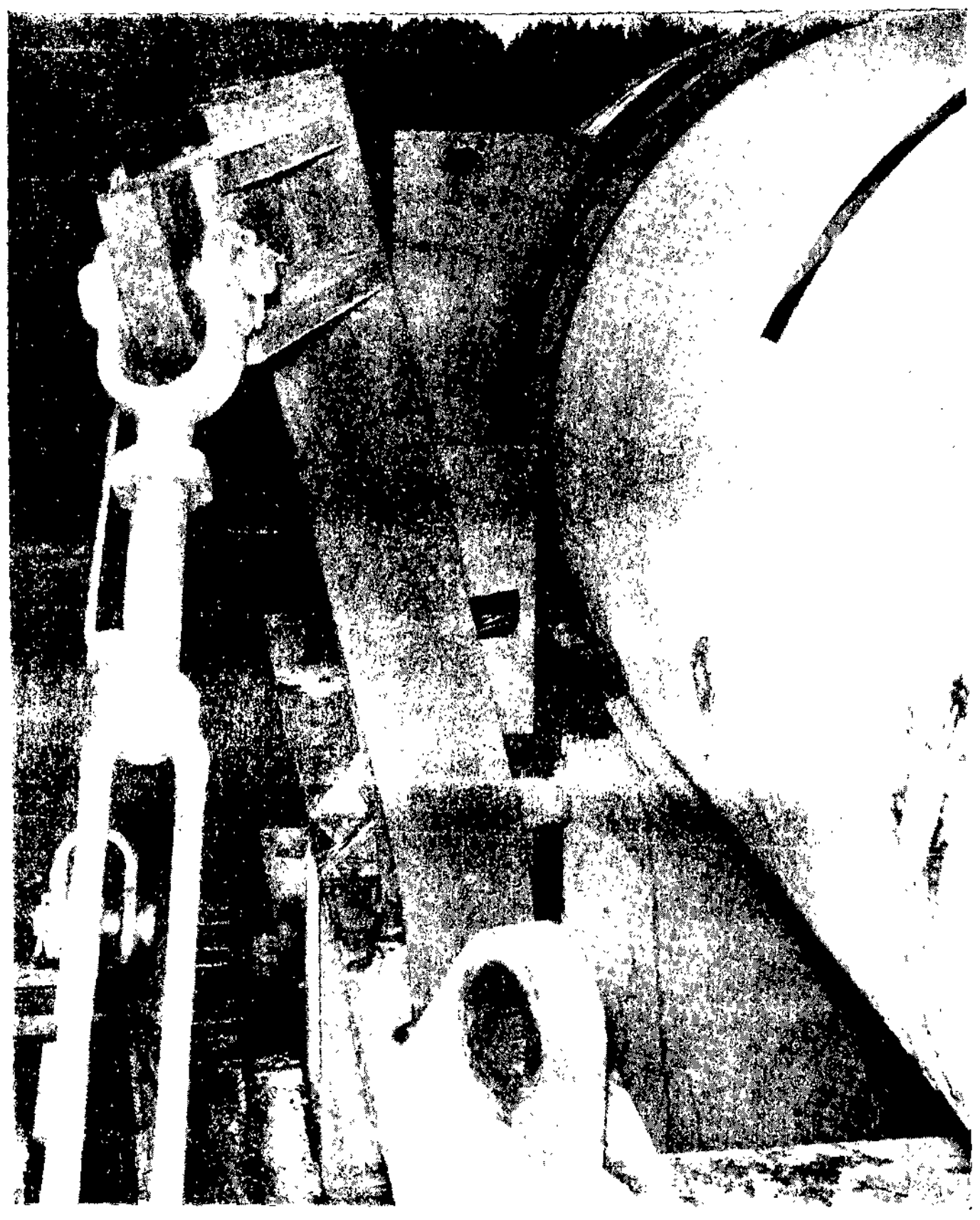

FIGURE 17. Bent Stanchion on Hallam Cask Cradle After Test No. 15 


\section{RESULTS}

\section{Measured Responses}

Measured peak forces at the coupler and longitudinal stop are given in Table 2 for six representative tests. The forces resulting from tests with railcars having standard couplers are illustrated in Figures 18 through 21. It is evident from the sharpness of the peaks that the high forces given in Table 2 are experienced very briefly. For example, the average longitudinal force in Figure 19 for Test 3 for the 0.050 second pulse time between 0.075 and 0.125 second is roughly 400,000 pounds compared with the peak value of 761,600 pounds. In determining the tiedown requirements for the cask load, consideration should be given to both the magnitude and duration of the force pulse.

TABLE 2

Measured Test Forces

\begin{tabular}{|c|c|c|c|c|c|}
\hline Test & Coupler & $\begin{array}{l}\text { Cask } \\
\text { Weight, } \\
\text { ton }\end{array}$ & $\begin{array}{l}\text { Impact } \\
\text { Speed, } \\
\text { mph }\end{array}$ & $\frac{\text { Peak Force }}{\text { Coupler }}$ & $\frac{1 \mathrm{~b}}{\text { Longitudinal }}$ \\
\hline 3 & St andard & 40 & 10.5 & $1,156,200$ & 761,600 \\
\hline 16 & St andard & 40 & 10.8 & $1,210,900$ & 782,000 \\
\hline $4 *$ & St andard & 40 & 10.7 & $1,221,200$ & $594,200 *$ \\
\hline 11 & St andard & 70 & 11.2 & $1,618,000$ & $1,025,000$ \\
\hline 13 & EOC Device & 40 & 11.1 & 493,000 & 303,300 \\
\hline 18 & Cushion UF & 40 & 10.7 & 308,400 & 153,244 \\
\hline
\end{tabular}

* Lower natural frequency. 
Test 4 results confirmed that lowering the natural frequency of the system would reduce the longitudinal tiedown load. Test 4 was essentially a duplicate of Test 3 except the system frequency was lowered by replacing an eight-foot bumper beam with a one-foot beam between the cask and the rigid stop. The effect of introducing this additional "spring" in the system can be seen by comparing Figure 18 with Figure 19. The time origin for these curves is based upon the initial physical movement of the coupler as determined by the displacement gage shown in Figure 10 . Figure 18 shows the coupler force, adjusted for velocity difference, of Test 3 compared with Test 4. In Figure 18, the coupler force traces for the two tests are almost the same through the first backlash. In contrast, Figure 19 shows that the peak longitudinal force exerted on the stop in Test 4 is substantially less than that of Test 3 (Table 2) as a result of lower natural frequency.

The effect of the railcar load is clearly demonstrated in Figures 20 and 21. As before, time zero in these curves begins at the first movement of the coupler when the test car strikes the lead anvil car. As expected, the maximum force of the heavier car (Test 11) is reached sooner than that of the lighter car (Test 3) as a result of the coupler being accelerated faster by the heavier load. The force in Test 11 has been adjusted for the velocity difference in both Figures 20 and 21 . 


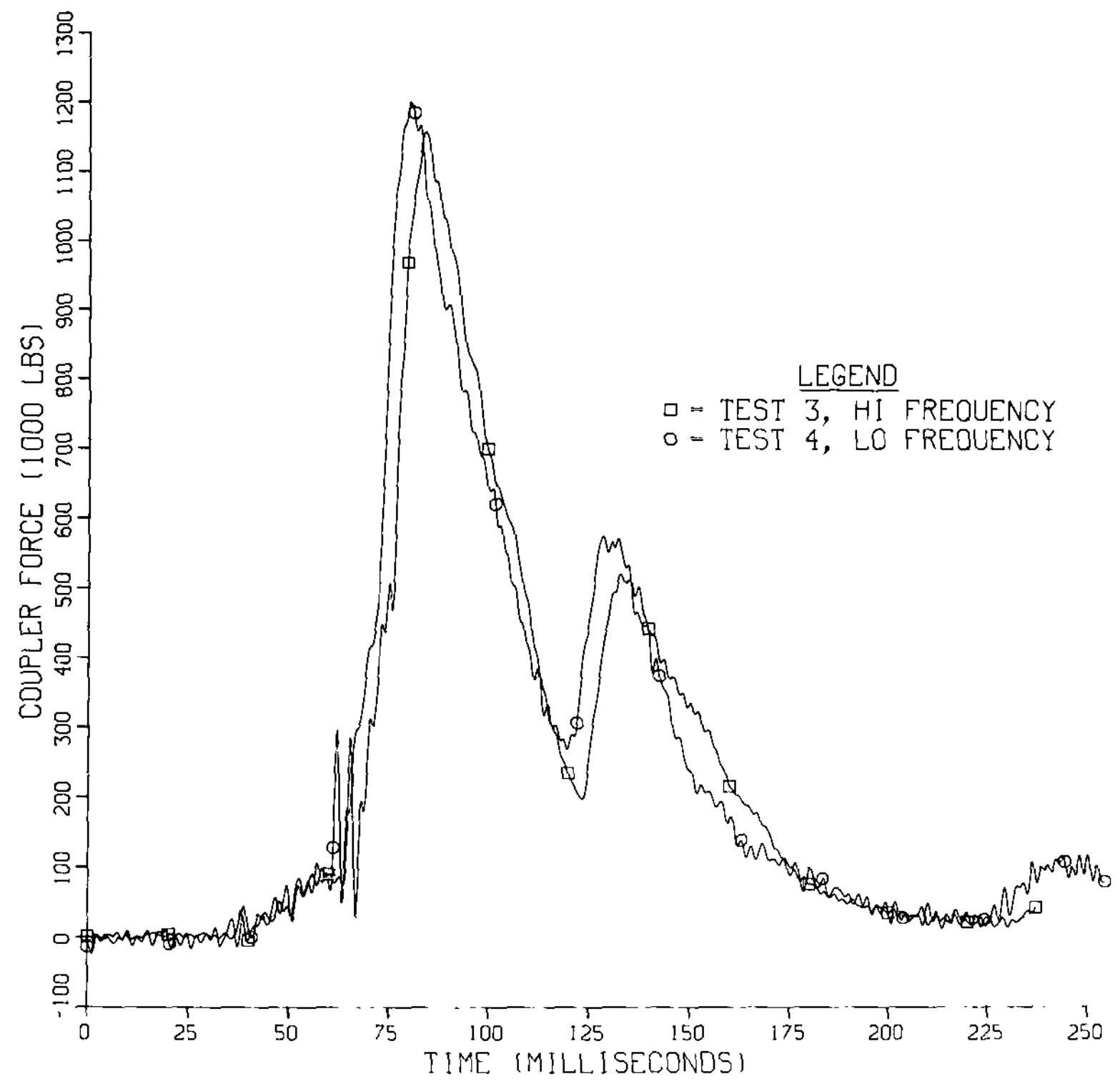

FIGURE 18. Coupler Force vs. Natural Frequency 


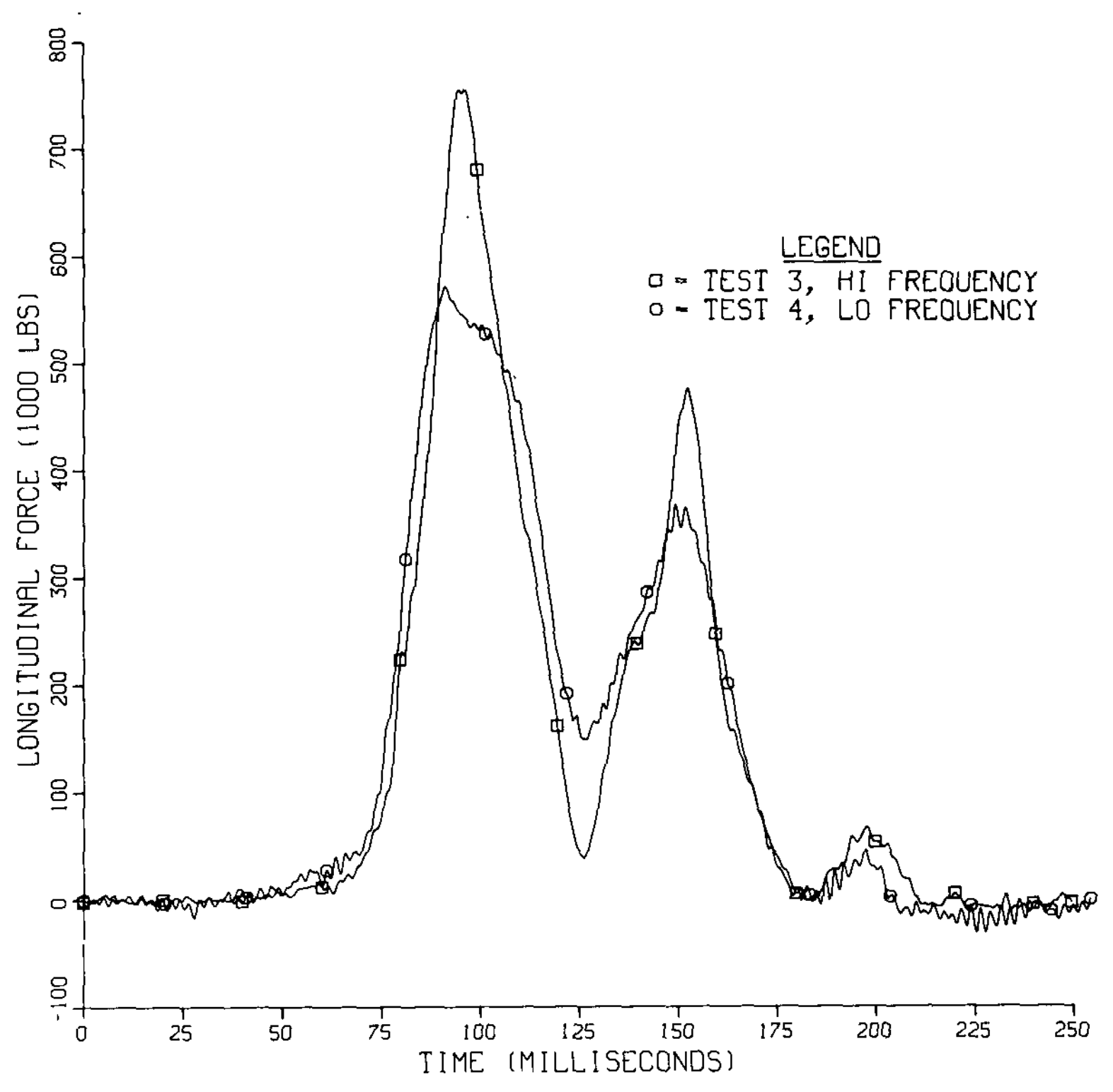

FIGURE 19. Longitudinal Force vs. Natural Frequency 


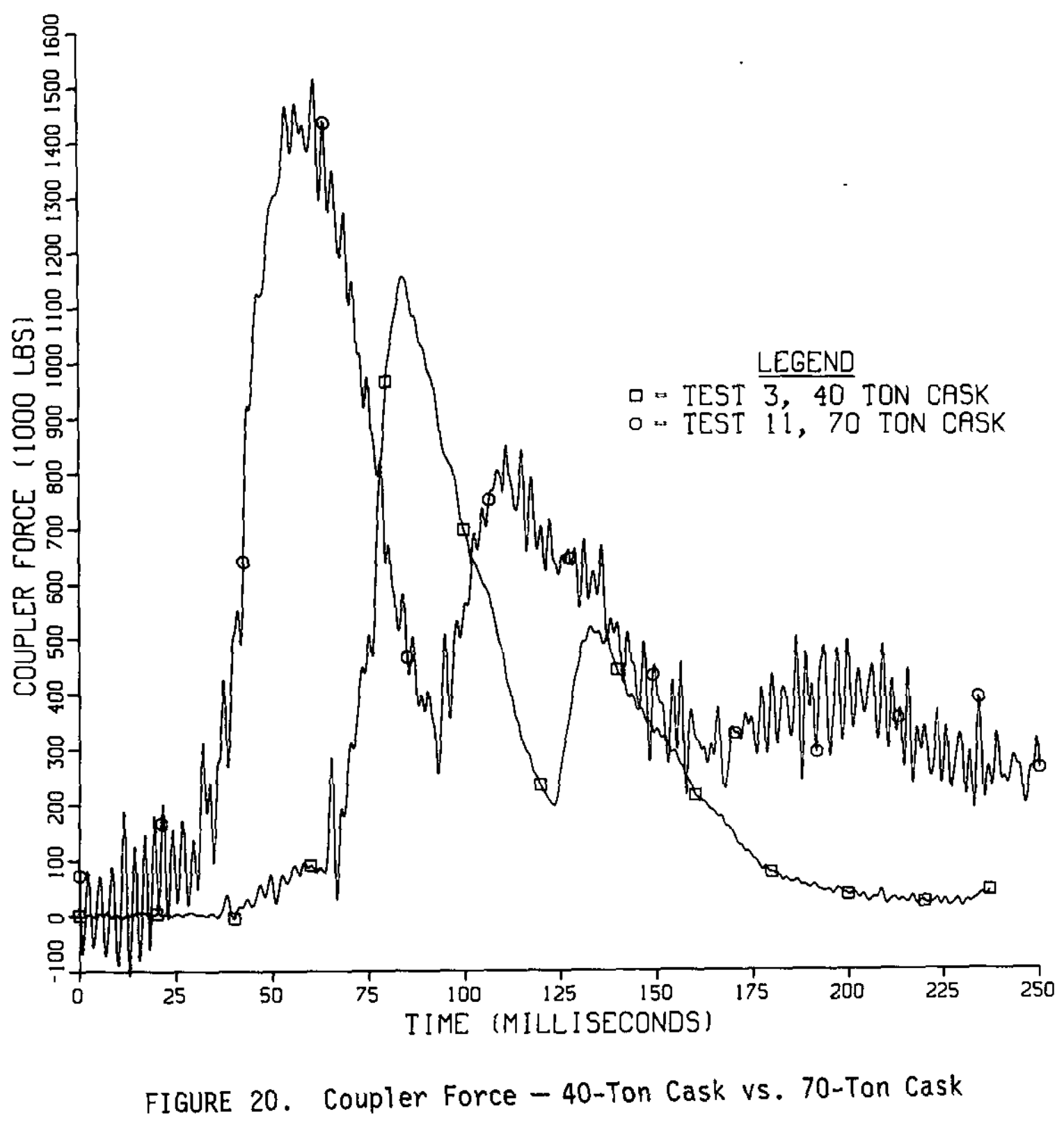




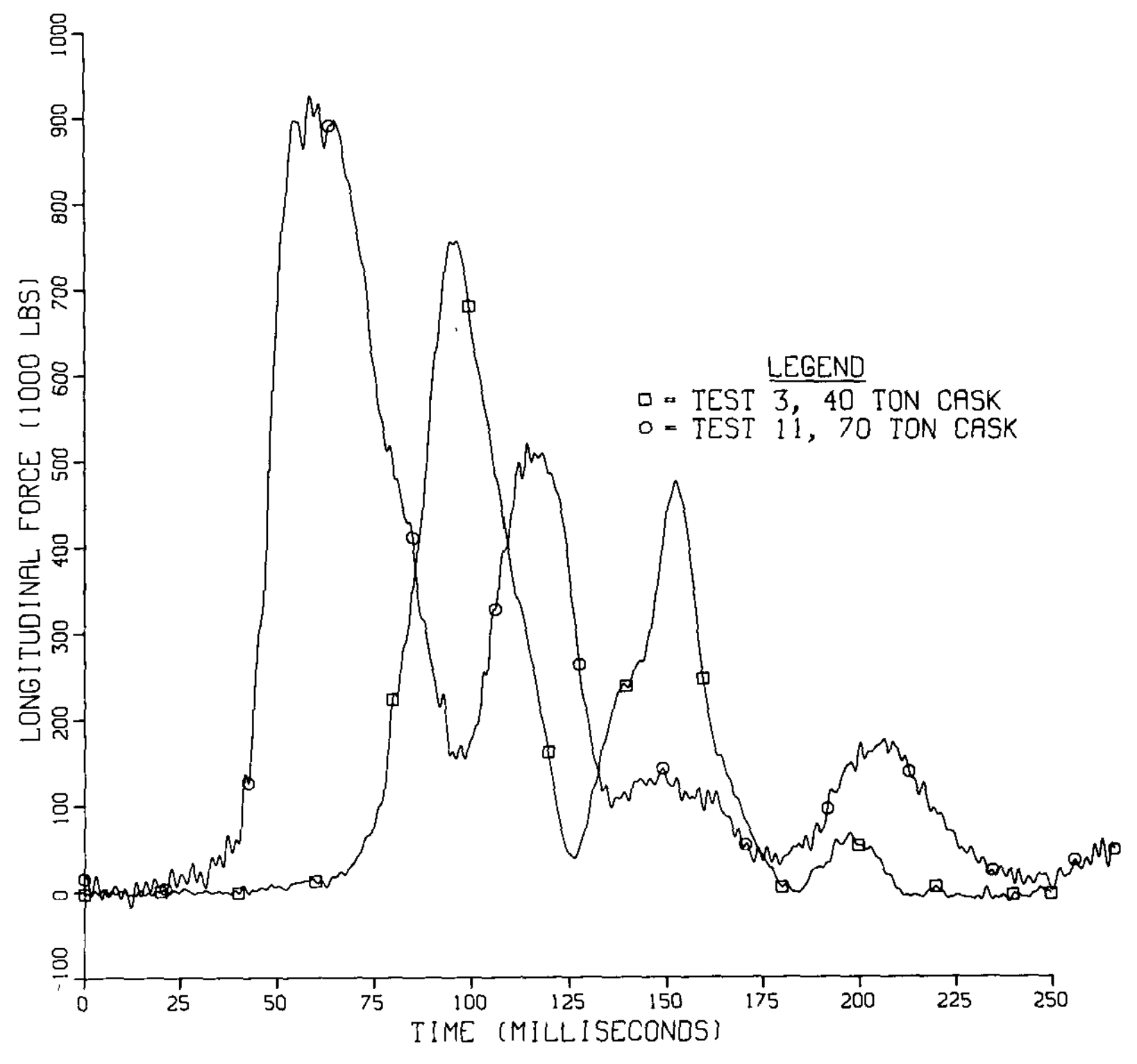

FIGURE 21. Longitudinal Force - 40-Ton Cask vs. 70-Ton Cask 
The EOC coupling device reduced the tiedown load during coupling substantially as compared with the standard coupler (Figures 22 and 23). In fact, as indicated in Figure 23, the cushion underframe car PS-22 reduced the tiedown load considerably below that with the EOC coupling device. The peak values are also given in Table 3 . Zero time in Figures 22 and 23 begins with the first movement of the coupler, and the forces in Tests 16 and 18 have been adjusted to the speed of Test 13. Note that the forces generated with the EOC coupling device and the cushion underframe are spread much more evenly through the coupling period than in the case of the standard coupler. Also, the maximum force occurs later with the two cushioning devices than with the standard coupler. While it is evident from Figure 23 and Table 3 that use of a cushioning coupler mechanism greatly reduced the tiedown load for the coupling operation, it should be remembered that the cushioning device was present only on the test car. How much effect cushioning devices might have in the anvil car train was not established.

TABLE 3

Effect of Coupling Mecheniem

$\begin{array}{llllll}\text { Test } & \text { Coupler } & \begin{array}{l}\text { Impact } \\ \text { Speed, } \\ \text { mph }\end{array} & & \frac{\text { Peak Force, lb }}{\text { Coupler }} & \text { Longitudinal } \\ 16 & \text { St andard } & 10.5 & & 1,210,900 & 782,000 \\ 13 & \text { EOC Device } & 11.1 & & 493,000 & 303,300 \\ 18 & \text { Cushion UF } & 10.7 & 308,400 & 153,200\end{array}$




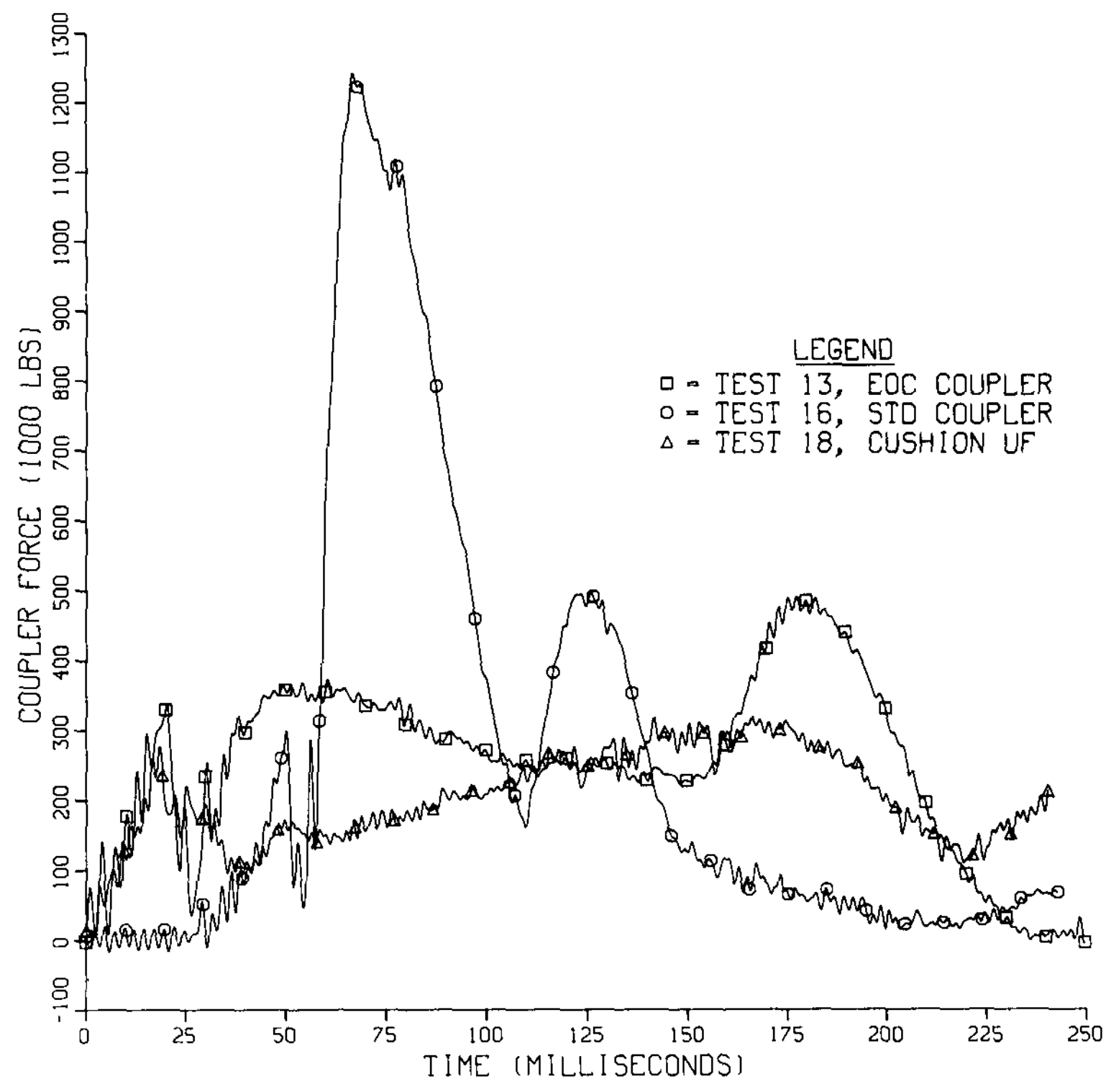

FIGURE 22. Coupler Force - Std Coupler vs. EOC Device vs. Cushion UF 


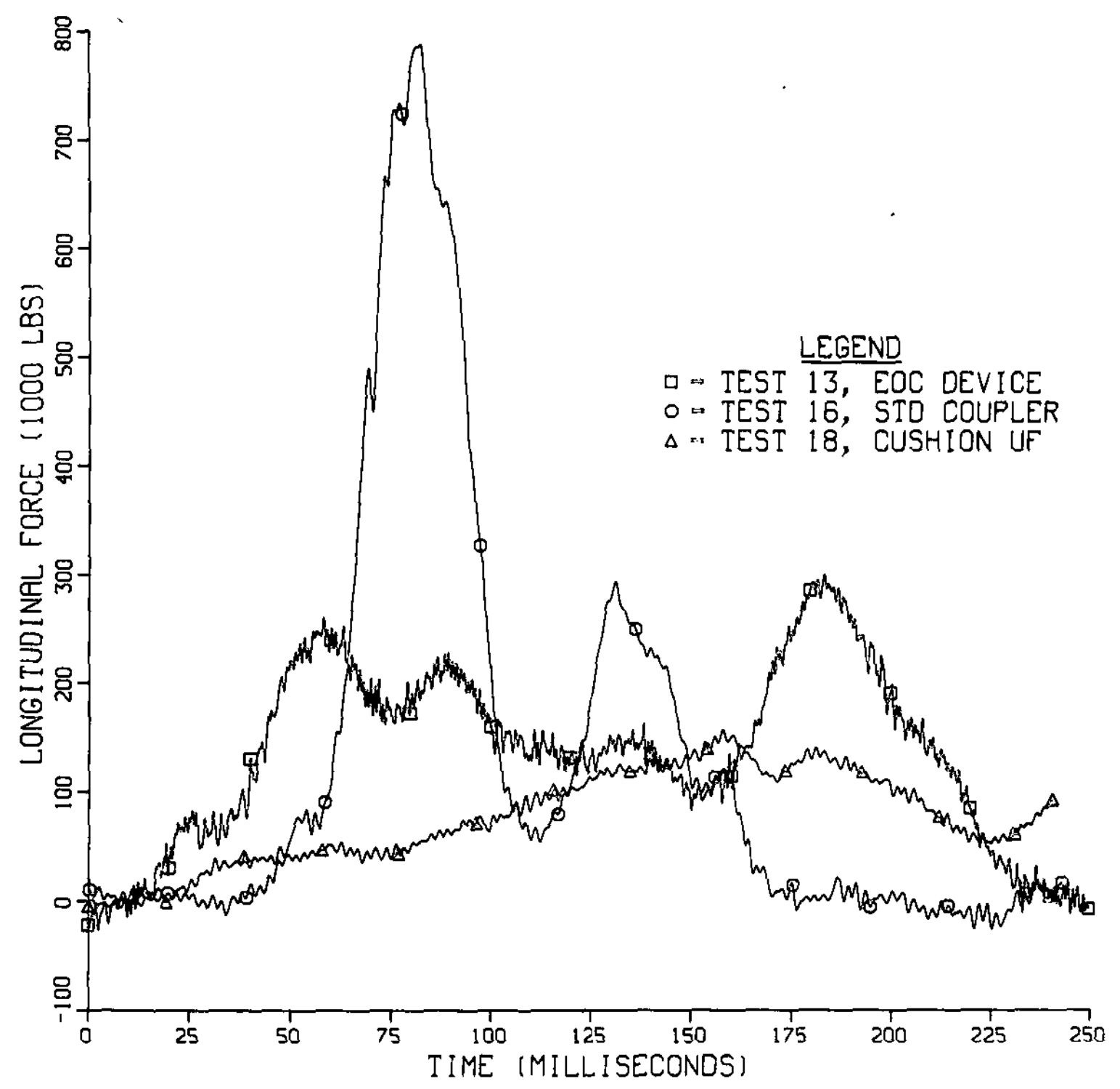

FIGURE 23. Longitudinal Force - Std Coupler vs. EOC Device vs. Cushion Underframe 
Figure 3 shows a typical test configuration with only ten one-inch cables (at approximately the same angle) securing the Hallam Cask to the railcar. The principal objective of these tests was to demonstrate that cables alone were not sufficient to safely tie a heavy cask to a railcar. However, as indicated in Figure 24, coupling with the EOC device reached $9.2 \mathrm{mph}$ before the safe working load (about 18,000 pounds) for a one-inch cable was exceeded. For the standard coupler, the cable exceeded the safe working load at $5.4 \mathrm{mph}$ (Table 4 and Figure 24). Note that time zero in Figures 24,25 , and 26 was arbitrarily chosen and did not correspond to the first movement of the coupler as in Figures 17 and 23. The cable force given is the average of two cable measurements. The force generated in all ten cables is assumed to be comparable.

TABLE 4

Effect of Slack Cables

\begin{tabular}{|c|c|c|c|c|c|c|}
\hline \multirow[b]{2}{*}{ Coupler } & \multicolumn{3}{|c|}{ Taut Cables } & \multicolumn{3}{|c|}{ Slack Cables } \\
\hline & Test & $\begin{array}{l}\text { Impact } \\
\text { Speed, } \\
\text { mph }\end{array}$ & $\begin{array}{l}\text { Peak } \\
\text { Cable } \\
\text { Force, } \\
\text { lb } \\
\end{array}$ & Test & $\begin{array}{l}\text { Impact } \\
\text { Speed, } \\
\text { mph }\end{array}$ & $\begin{array}{l}\text { Peak } \\
\text { Cable } \\
\text { Force, } \\
\text { lb } \\
\end{array}$ \\
\hline EOC Device & 8 & 9.2 & 21,300 & 9 & 9.2 & $34,200 *$ \\
\hline St and ard & 14 & 5.4 & 37,500 & 15 & 6.5 & 49,800 \\
\hline
\end{tabular}

ॠ This instrument response was somewhat erratic. 


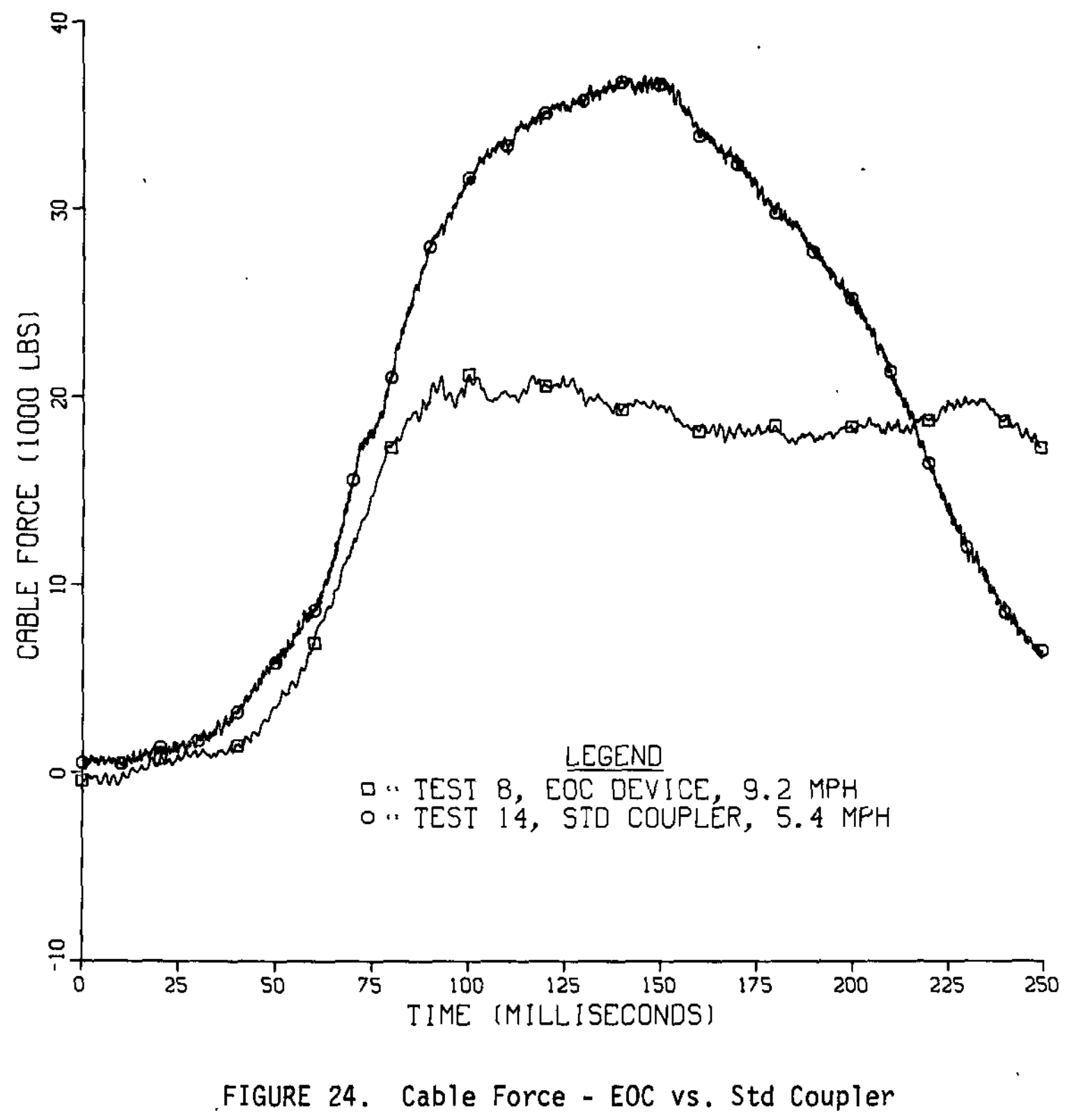




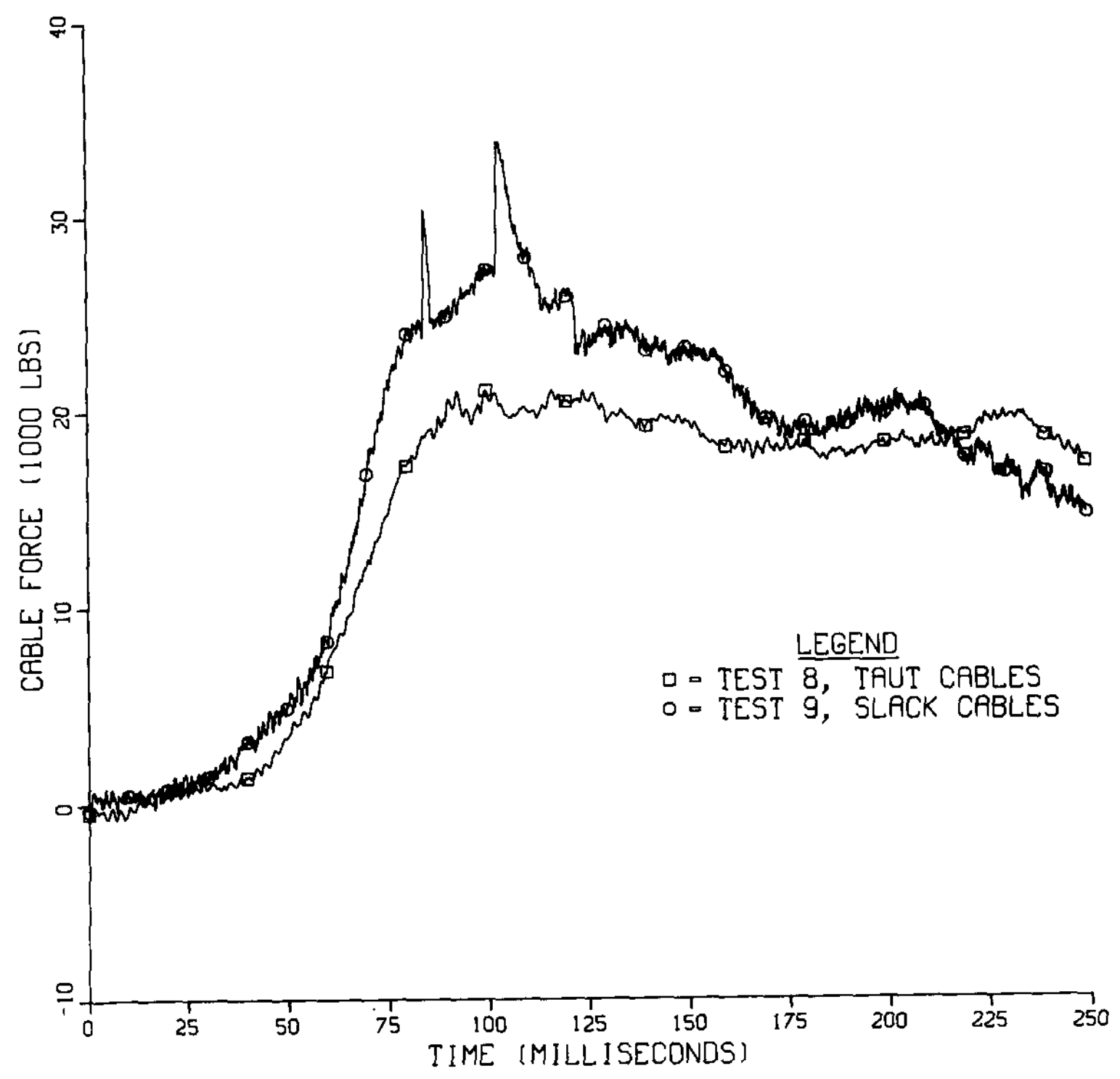

FIGURE 25. Cable Force - Taut vs. Slack Cables (EOC) 


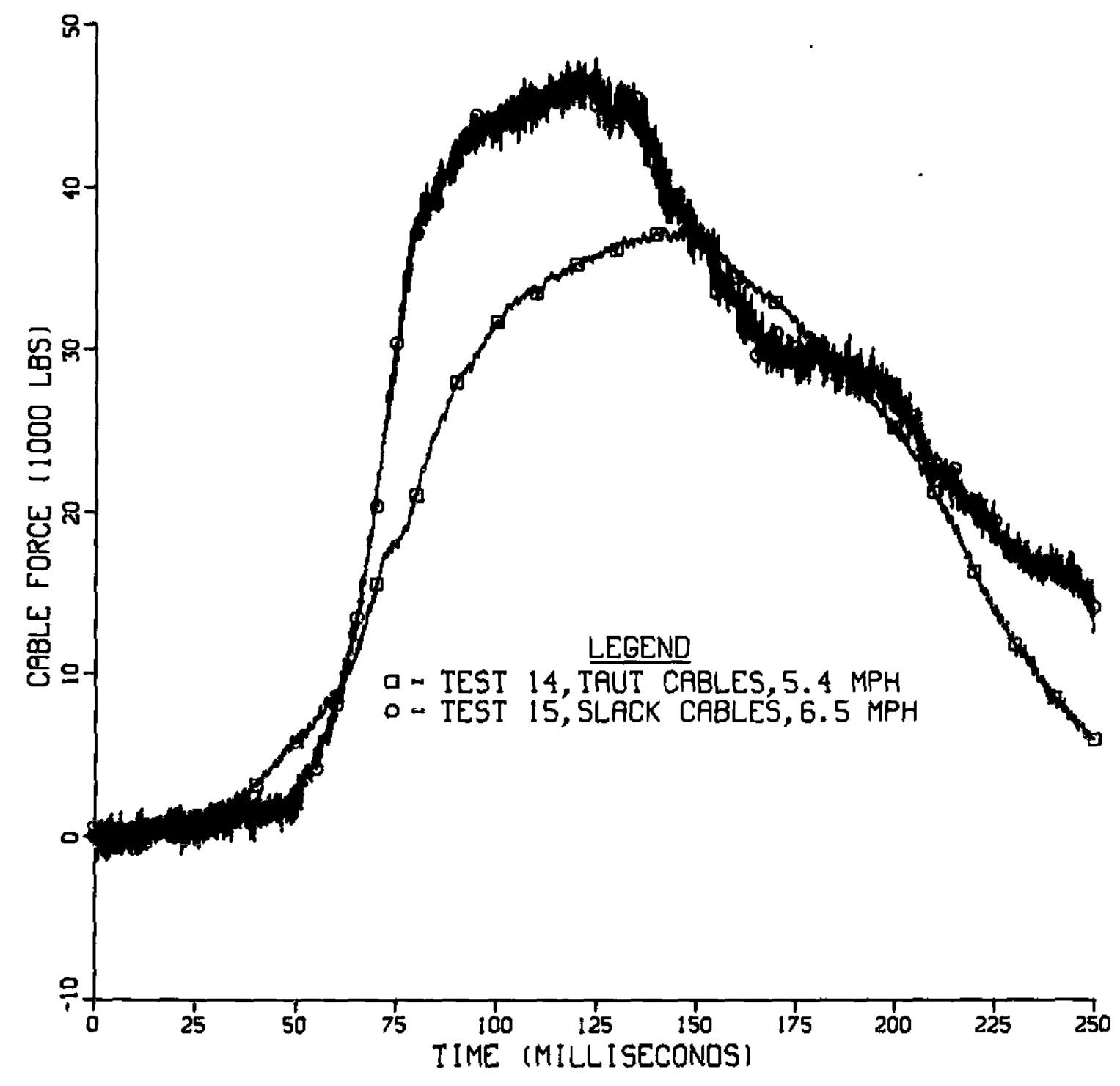

FIGURE 26. Cable Force - Taut vs. Slack Cables (Std) 
The importance of removing excessive slack in tiedown cables is evident from Figure 26 and Table 4. Test 15 has not been adjusted for the velocity difference from Test 14 in Figure 26. Even with the EOC coupling device, slack cables generate greater tiedown forces than taut cables as seen by comparing the results of Tests 8 and 9. The comparable cable force trace of these tests is given in Figure 25 .

The data generated from measured vertical forces in bolts and cables during the tests were too inconsistent for reliable interpretation and therefore are not included in this report.

The accelerometer data measured during the tests are currently under study at Sandia, LASL, and HEDL. Reports from those organizations will include these data.

\section{Observations}

Several conclusions can be drawn from observation of the tests without the need for measured data. Overall, a tiedown of fixed longitudinal stops combined with flexible cables for vertical and lateral restraint was found to be the optimum configuration tested. Cables were shown to be satisfactory for securing casks vertically and laterally (Tests $5,12,13,16$, and 18). Conversely, cables alone were not practical to secure heavy casks longitudinally (Tests 14 and 15) because too many cables would be required. The importance of preventing excessive slack in tiedown cables was observed in Test 15 when the sliding cask bent several of the stanchions (Figure 15) to which the top of the cables were anchored.

The longitudinal stop was the key element in the tiedown configurations of this test program. These stops were welded in place with a minimum of 150 in. ${ }^{2}$ of weld metal for each stop on each railcar. Bolting of the stops was considered, but rejected, because the bolting adapters would be much more complex and expensive than welding. Also, welding provides positive shear restraint for the high longitudinal loading on the stops, whereas the friction restraint provided by bolting the stops was believed inadequate. It is assumed that most railcars converted to haul heavy casks in the future will be dedicated for this purpose long enough to spread the cost of installing longitudinal stops over a number of transportation runs and to avoid the need for frequent removal and rewelding of the stops.

Although bolting was found to be acceptable for securing casks vertically and horizontally, several disadvantages were evident with this approach. To anchor bolts well enough to tie a cask to railcar underframing requires expensive bolt extensions, cross beams, and other adapters. Also, galling of bolts and nuts was a problem encountered in the tests. Cables were much less expensive, simpler, and more flexible. 


\section{PLANNED TEST PREPARATIONS}

\section{Seaboard Cosstline Railcars}

The railcar considered most typical in the test program was the P-22 sCL car (Figures 1 and 4) designated $I$ in Table 1 . A mechanical arrangement of this test car loaded with the 40-ton Hallam Cask or the 70-ton scrap cask is given in Figure 7. To prepare the car for testing, planking was removed from the deck and bulkhead to accommodate the casks, rigid stop, and tiedown layouts. All ballast tanks and brake linkages were also removed as required for tiedown layouts. The brakes were made inoperable on the test railcars. A heavy, rigid stop was secured in place with a minimum of 150 in. $^{2}$ of weld metal. A spacer plate was installed between the rigid stop and the bulkhead to distribute part of the load evenly to the bulkhead. Special lugs were welded on the bottom inside of the outer railcar sills to anchor tiedown cables to the car. Similar preparations were made to the cushion underframe PS-22 SCL car (Figure 15) designated II in Table 1.

\section{Separate Prefabrication}

In addition to partial prefabrication of test components attached to railcars (such as the rigid stops), auxiliary components were made for tiedown adapters, etc. As shown in Figure 7 , bolt extensions were provided to tie the cask base to the cross beams, which were made to span the structure underneath the test railcars. The three bumper beams between a cask and rigid stop were made from reinforced 14-inch, 8-foot, 167-pound WF beams. Shims were placed between bumper beams and stops as necessary to assure metal-to-metal contact. One-inch-thick steel deck plates were used to distribute the cask load on an uneven deck and to minimize friction between the cask and car. Prefabricated cables cut to length, with eye thimbles included, were used for all tests with tiedowns designated " $C$ " or " $D$ " in Table 1 . Special clevises were fabricated for the two instrumented clevis pins used during the tests, and solid cable thimbles were machined to accurately receive the clevis pins. 


\section{Hallam Cask Cradle}

The cylindrical Hallam Cask was designed to be loaded into a cradle (i.e., shipping frame) having a trunnion saddle at one end and a cradle boss at the other. A saddle collar secured the cask trunnion, and a holddown collar held the cask body to the cradle boss (Figure 4). A spare cradle was modified as illustrated in Figures 7 and 16 for this test program. Tool boxes were cut off the sides of the cradle frame; bolt holes were drilled through the cradle side beam flanges; and the impact end of the cradle was reinforced. Ten stanchions were welded on top of the cradle to create an indirect means of connecting tiedown cables to the cask high enough to provide for cable rigging angles of $\geq 45^{\circ}$ (Figures 3 and 27 ).

The rectangular 70-ton cask was tied down directly to the SCL P-22 test car with bolts. The bolt holes in the feet were enlarged to avoid shear stress, and the cask bumper plate was reinforced at the impact end.

\section{Union Carbide Railcar}

As described earlier, the special Union Carbide test railcar, designated Car III in Table 1, had a welded superstructure, above the deck surface, which required extensive torch cutting to provide flat space for the 70 -ton cask or Hallam Cradle. Appropriate cutting of the superstructure was also necessary to install rigid stops and to permit unrestricted installation of tiedown cables. Rigid stops were welded on each end of this car (Figures 16 and 27), because both ends were impacted during the test program. Air ballast tanks and brake linkages were removed as needed, and lugs were welded on the car underframe to anchor tiedown cables (Figures 16 and 27). The special 15-inch FreightMaster ${ }^{\star}$ EOC coupling device was installed by Kustom Kar Company in Green Cove Springs, Florida (Figures 3 and 14) to replace the standard coupler mechanism on one end of the car. Following the preliminary test program, this car was reconditioned by installing a new draft gear for the standard coupler on the car end opposite the EOC device, rewelding certain broken structure welds, repairing both center plates, and replacing two worn axles and two sets of wheels. 


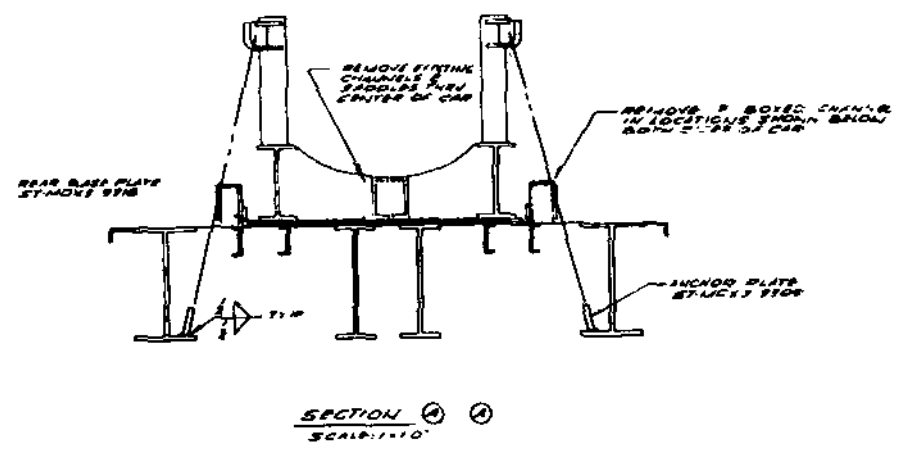

Un
U

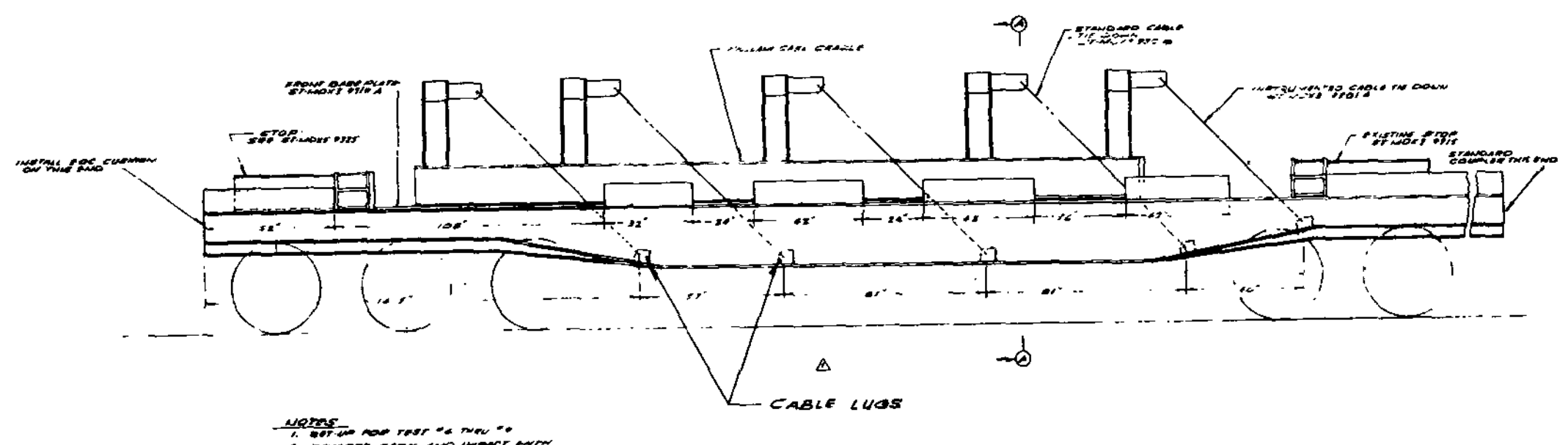

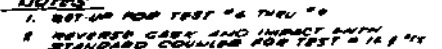

FIGURE 27. Ten-Cable Tiedown of Hallam Cask Cradle to Union Carbide Railcar 


\section{REFERENCES}

1. Draft RDT Standard, Fuel Shipping Container Tiedown for Rail Transport. USDOE RDT. F 8-12, Division of Nuclear Power nevelopment (March 1977).

2. S. R. Fields. SAVIT - A Dynamic Mode1 to Predict Vibratory Motion Within a Spent Fuel Shipping Cask - Rail Car System. HEDL TME 77-45, Hanford Fngineering Development Laboratory, Richland, WA (March 1978).

3. P. V. Kasbeker, et al. "Dynamic Simulation of. Freight Car and Loading During Impact." Journal of Engineering for Industry Transactions of Society of Mechanical Fngineers, 859 (November 1977).

4. T. Willis and $K$. Shum. "A Nonlinear Mathematical Model of the Dynamics of a Railroad Freight Car/Freight Element." American Societv of Mechanical Fngineers. Paper 76-DE-42. (April 1976).

5. R. J. Bartholemew. Cargo Response to Railcar Impact and Tiedown Load Analysis. LA-7469-MS, Los Alamos Scientific Iaboratory, Los Alamos, NM (September 1978).

6. C. F. Magnuson and L. T. Wilson. Shock and Vibration Environments for Large Shipping Containers on Railcars and Trucks. SAND-76-0427, NUREG-766510, Sandia Laboratory, Albuquerque, NM (July 1977). 